\title{
Study of education environments in terms of physical/spatial variables in regional primary boarding schools"
}

\author{
Ersin TÜRE ${ }^{* * *} \quad$ Suna Arslan KARAKÜÇÜK ${ }^{* * * *}$
}

\begin{abstract}
In this study with the interdisciplinary approach, theoretical aspects of Educational Science, Environmental Psychology and Architecture have been met on a common denominator. The study has been conducted in three stages. In the first stage, through document analysis, the spaces that must be present in Regional Primary Boarding Schools (RPBS) and in what indoor and outdoor spaces the students spend most of their time have been determined. In the second stage, the instrument of "Physical/spatial conditions satisfaction questionnaire" has been applied to the universe of the study. Data has been analyzed with the chi-square technique in SPSS16.0 package program and the general problems of the physical/spatial conditions pertaining to RPBSs and in what RPBSs these problems have been observed more have been determined. In the third stage, "focus group interviews" and "mechanical observations" concerning the reasons of the specified problems have been performed in determined RPBSs. Data analysis has been performed with the QSR Nvivo 8 program. Satisfaction/dissatisfaction levels of the students of RPBS concerning physical/spatial conditions and the reasons of the related problems have been determined. Suggestions have been offered to prepare more effective educational environments.
\end{abstract}

Keywords: RPBS, Educational Environments, Physical/Spatial conditions, education architecture.

\footnotetext{
* "This work is supported by the Scientific Research Project Fund of Cumhuriyet University under the project number Eğit-016". This article has been produced from the master thesis called "Study of Education Environments in Terms of Physical/Spatial Variables in Regional Primary Boarding Schools".

Res. Assist., Ankara University, Faculty of Educational Sciences, Department of Curriculum Development in Education, Cebeci, Ankara. E-mail: ersinture@ mynet.com Assist. Prof. Dr., Cumhuriyet University, Education Faculty, Department of Educational Sciences, Sivas. E-mail: suna_karakucuk@yahoo.com
} 


\section{SUMMARY}

Purpose and Significance: The objective of the study is to reveal the perceptions related to physical/spatial conditions of students who study at Regional Primary Boarding Schools (RPBS) and what the problems and their causes are regarding these conditions within the framework of the school-individual relationship and environment-individual relationship of environmental/spatial psychology, which are subjects of educational sciences. In this study with an interdisciplinary approach, the theoretical aspects of the disciplines of educational science, environmental psychology, and architecture have been met on a common denominator and their interrelations have been discussed.

Methods: In this study, case study has been adopted as the research design. Through this integrated approach, the questionnaire technique, which is a quantitative technique, has been utilized and data variation has been ensured with qualitative techniques such as document analysis, observation, and focus group interview techniques. The study has been conducted in three stages. In the first stage, through document analysis, the number of students, the spaces that must be present in RPBS and the internal and external locations where students spend the most time have been determined. In the second stage, the "Physical/spatial environment condition satisfaction questionnaire," whose measurement reliability and validity pertaining to the determined internal and external locations have been ensured, has been applied to the universe of the study. The obtained data has been analysed with the chi-square technique in the SPSS16.0 program and the general physical/spatial condition problems of RPBS and in what RPBSs these problems are encountered at a higher rate have been determined. In the third stage, the RPBS that is determined as a sample has been visited and focus group interviews and mechanical observation have been performed in order to understand the sources of the determined problems. The observation and interview records have been expressed in writing and content analysis has been performed with the help of the QSR Nvivo 8 program.

Results: The dissatisfaction reasons pertaining to each space, which is relevant to the problem of the research, have been conceptualized under four themes. These have been discovered as "the cycle of space-individual interaction", "space demonstrating integrity within itself and with the others", "need for creating individual space," and "the effects of structural/architectural deficiencies on human behaviour".

Discussion and Conclusions: At the conclusion of the study, some suggestions have been presented to prepare more effective educational environments by determining satisfaction levels and perceptions pertaining to physical/spatial conditions of RPBS students whose apparent living spaces are schools and their 
environments and by revealing the main sources of the problems pertaining to these conditions.

A need for education architecture, which is the common denominator of architecture, educational science and environmental psychology (spatial psychology), has emerged for Turkey. The theoretical structure of education architecture must be completed as soon as possible with the interdisciplinary studies and its use in practice must be ensured. As for the method in this study, the rich data has been obtained by using qualitative and quantitative techniques together as in a complementary manner. The same theoretical structure has been obtained with the results of the qualitative research performed in different regions. As a result, it has been observed that qualitative and quantitative methods support each other when they are used responsively together in a compatible manner. 


\title{
Yatılı İlköğretim Bölge Okullarında Ĕgitim Ortamlarının Fiziksel/Mekânsal Değişkenleri Açısından İncelenmesi*
}

\author{
Ersin TÜRE**
}

\author{
Suna Arslan KARAKÜÇÜK ${ }^{* * *}$
}

\begin{abstract}
ÖZ. Bu çalışmada disiplinlerarası bir yaklaşımla; Eğitimbilim, Çevresel Psikoloji ve Mimarlık alanlarının kuramsal boyutları ortak bir paydada buluşturulmuştur. Çalışma üç aşamada gerçekleştirilmiştir. Birinci aşamada; doküman analizi yöntemi ile YİBO'larda bulunması gereken mekânlar ve öğrencilerin hangi iç ve dış mekânlarda en çok zaman geçirdikleri saptanmıştır. İkinci aşamada, belirlenen mekânlara ait "Fiziksel/mekânsal koşul memnuniyet anketi" çalışma grubuna uygulanmıştır. Veriler, SPSS16.0 paket programında Ki-Kare tekniği ile analiz edilerek; YİBO'lara ait fiziksel/mekânsal koşulların genel sorunları ve bu sorunların hangi YİBO'larda daha fazla görüldüğü saptanmıştır. Üçüncü aşamada, belirlenen YİBO'larda, saptanan sorunların nedenlerine ilişkin "odak grup görüşmeleri” ve "mekanik gözlemler" yapılmıştır. Veri analizi, QSR Nvivo 8 programıyla yapılmıştır. YİBO öğrencilerinin, fiziksel/mekânsal koşullara ilişkin memnuniyet/memnuniyetsizlik düzeyleri ve ilgili sorunların nedenleri belirlenmiştir; daha etkili eğitim ortamlarının hazırlanması için öneriler sunulmuştur.
\end{abstract}

Anahtar Sözcükler: YİBO, eğitim ortamları, fiziksel/mekânsal koşullar.

\footnotetext{
* Bu çalışma, Cumhuriyet Üniversitesi Bilimsel Araştırma Projeleri (CÜBAP) tarafından Eğit-016 proje numarası ile desteklenmiştir. Bu çalışma "Yatılı İlköğretim Bölge Okullarında Eğitim Ortamlarının Fiziksel/Mekânsal Değişkenleri Açısından İncelenmesi” adlı yükseklisans tezinden üretilmiştir.

Araştırma Görevlisi, Ankara Üniversitesi, Eğitim Bilimleri Fakültesi, Eğitimde Program Geliştirme Bölümü, Cebeci, Ankara. E-posta: ersinture@ mynet.com

**** Yrd. Doç. Dr., Cumhuriyet Üniversitesi, Eğitim Fakültesi, Eğitim Bilimleri Bölümü, Sivas. E-posta: suna_karakucuk@yahoo.com
} 


\section{GíRiş}

Eğitim, insanı bireyselleştirme ve/veya toplumsallaştırma süreçlerini, amaca uygun olarak kurgulanmış bir çevrede gerçekleştirmektir. Fidan ve Erden (1998:8) eğitimin, "seçilmiş ve kontrollü bir çevrenin (özellikle okulun) etkisi altında sosyal yeterlik ve en uygun bireysel gelişme sağlayan sosyal bir süreç" olduğunu belirtmişlerdir "Eğitim, bir çevre etmenidir. Başka bir deyişle, insana önceden belirlenen davranışları kazandırabilecek nitelikte düzenli bir çevre sunmak demektir''(Başaran, 1994:13). Eğitim uygun çevresel koşullarda gerçekleştirildiğinde amacına ulaşması mümkündür.

$\mathrm{Bu}$ araştırmada Eğitimbilimleri, Çevresel Psikoloji ve Mimarlık alanlarının kavramları ortak bir paydada kullanılarak, eğitim tanımı farklı bir çerçevede ele alınmıştır. "Eğitimin çok boyutlu doğası gereği eğitimciler başka alanların uzmanlarından yardım ve destek almak zorundadırlar", (Baykal, 2004). Bu bağlamda, Eğitimbilimlerinin konusu olan eğitim ortamlarının fiziksel/mekânsal koşulları ile Çevresel Psikolojinin konusu olan çevre-birey ilişkisi ve Mimarlık alanının konusu olan mekân tasarlama işi bütüncül bir yaklaşımla ele alınarak, eğitim ortamlarının fiziksel koşulları incelenmektedir.

Eğitim programlarının tasarlanması kadar uygulanabilir olması da önemlidir. "Eğitim programlarının uygulanabilmesinde bina, araç gereç gibi insan gücü dışı kaynaklar da önem taşımaktadır. Okul binası, araç gereç ve diğer donanım programda yer alan hedeflere ulaşılmasında yardımcı olacak nitelikte olmalıdır' (Fidan ve Erden,1998: 18). Bir öğretim sisteminin bileşenleri; hedefler, fiziksel ortamlar, toplumsal doku, öğretim donanımları, yöntemler ve öğretmendir. Fiziksel ortamlar tüm bu bileşenleri içinde barındırır (Baykal, 2004). Fiziksel ortamlarla, insan davranışları/deneyimleri arasında karşılıklı bir ilişki vardır (Gürkaynak, 1988). Bu bağlamda eğitim ortamlarının yapısal düzenlenmesinde Eğitim Mimarisi ve Çevresel Psikoloji alanları ile işbirliği ve işbütünlüğü sağlanması gerekmektedir.

Eğitim olgusu kendine özgü mekânlarda gerçekleştirilmektedir. "Mekân; öznenin özneyle ya da nesnelerle buluştuğu/eylemlendiği yerdir" (Karaküçük, 2004: 78). Eğitim mekânları da, öğretmenin ve öğrencinin birbirleriyle ya da bina, derslik, bahçe vd. mekânsal birimlerle buluştuğu yerlerdir. Bu bağlamda eğitim mekânları psikolojik ve eğitimsel etkiler barındırır; bu etkilerin tartışılması, araştırılması gerekmektedir.

Eğitim mimarisi, öğretmen, öğrenci ve yönetici gibi canlı bileşenlerin ihtiyaçları, algıları ve önerileri çerçevesinde, eğitim programlarıyla bütünleşik mekânları ve okul yapılarını var etme çabası içinde olmalıdır. Eğitim mekânlarının tasarlanması, eğitim-öğretim programları hakkında bilgi sahibi olmayı gerektirir. Bu araştırma, eğitim programlarının bilinen 
dört boyutuna uygun mekânların düzenlenmesinin eğitim süreçlerine olumlu katkısı olacağı tezine dayanmaktadır. Şöyle ki; eğitim hedef ve amaçlarının gerçekleştirilebileceği mekân, içeriğin somutlanabilirliğini arttıran mekân, eğitim durumlarının uygulanabileceği mekân ve değerlendirmenin sağlıklı yapılabileceği bir mekân.

$\mathrm{Bu}$ çalışma eğitim sistemi içinde sadece eğitimsel faaliyetlere değil, yaşamsal faaliyetlere de yer veren bir okul türü olan Yatılı İlköğretim Bölge Okullarında (YİBO) gerçekleştirilmiştir. YIBBO'lar, Türkiye'de nüfusun az ve dağınık olduğu yerleşim yerlerinde (köy, mezra, kom, oba) zorunlu eğitim çağına gelmiş çocukların sekiz yıllık eğitim ihtiyaçlarını karşılamak amacıyla kurulmuş okullardır (MEB, 2008). Bu okulların eğitim-öğretim ortamlarının öğrencilerin tüm yaşam alanı olduğu söylenebilir.

Bu çalışma, disiplinlerarası yaklaşımla; YİBO'ların eğitim ortamlarında öğrencilerin kendileri için tasarlanan mekânlara ilişkin memnuniyet/memnuniyetsizlik düzeylerini ve memnuniyetsizlik nedenlerini saptama çabasındadır.

\section{Problem}

$\mathrm{Bu}$ çalışmanın ana problemi YİBO'larda fiziksel/mekânsal koşullara ilişkin öğrenci algılarının ve bu algıların kaynaklandığı durumların araştırılmasıdır. Bu bağlamda, aşağıdaki alt problemlere de yanıt aranmıştır:

1) Türk Standartları kurallarına göre eğitim öğretim alanlarında bulunması gereken mekânlar nelerdir?

2) Sivas İlinde eğitim veren YİBO'larda öğrencilerin en çok zaman geçirdikleri okul içi/dışı mekânlar nelerdir?

3) YİBO öğrencilerinin, okullarının fiziksel/mekânsal koşullarına ilişkin memnuniyet düzeyleri nedir?

a. Öğrencilerin memnuniyetsizlik düzeyleri fiziksel/mekânsal koşulların hangi özelliklerinde daha yüksektir?

b. Söz konusu memnuniyetsizlik durumu çalışma grubunu oluşturan okulların hangilerinde daha çok görülmektedir?

$\mathrm{Bu}$ önsel sorularla, süreci araştırmanın asıl bulgularına taşıyacak olan nitel çalışmanın kapsayacağı birimleri, soruları ve örneklemini belirlemek amaçlanmıştır. $\mathrm{Bu}$ bağlamda, çalışmadaki nicel çalışma aşamasının sonuçları, nitel çalışma aşamasının kapsamını ortaya çıkarmıştır. Böylece araştırmanın dördüncü problemi olan;

4) Nitel çalışmanın örneklemini oluşturan okullarda memnuniyetsizlik yaratan fiziksel/mekânsal koşulların nedenleri nelerdir?" sorusu yanıtlanmaya çalışılmıştır. 


\section{Amaç ve Önem}

$\mathrm{Bu}$ araştırmanın temel amacı Çevresel Psikoloji, Eğitimbilim ve Mimarlık bilimlerinin kesiştiği alana katkı sağlamaktır. Bu anlamda eğitim ortamlarının fiziksel koşullarını YIBBO örneğinde araştırmak ve bu ortamın öncelikli kullanıcıları olan öğrencilerin mekânsal algılarını ve memnuniyet düzeylerini saptamaktır. YİBO'ların fiziksel/mekânsal koşullarına ilişkin sorunların saptanması, bunların temalaştırılması ve bu temaların yorumlanmasıyla Eğitimbilimleri alanında yeni çıkarımlarda ve önerilerde bulunmak amaçlanmıştır. Aynı zamanda fiziksel mekânsal koşullarla, eğitim programları arasında öğrencinin mekânsal algıları temelinde bağ kurulması amaçlanmaktadır.

$\mathrm{Bu}$ çalışma bütünsel anlamda, bireylerin içinde yaşadıkları çevreleriyle olan ilişkilerini sorgulayabildiği anlamda önem taşımaktadır. Eğitim boyutunda ise YIBBO'ların eğitim ortamlarının fiziksel/mekânsal koşulları ve okul mimarisi konularındaki az sayıdaki çalışmalara katkı sağlaması açısından da önem taşımaktadır. Araştırmanın bir diğer katkısı, YİBO’larda eğitim öğretim gören öğrencilerin içinde yaşadıkları eğitim çevrelerine ilişkin duyuşsal, devinimsel ve duygusal algılarına dikkati çektiği oranda gerçekleşecektir.

\section{Sinırlılık}

Araştırmanın kuramsal çerçevesi, Eğitimbilim, Çevresel Psikoloji ve Mimarlık alanlarında ulaşılabilen kaynaklarla sınırlıdır. Uygulama boyutu ise, Sivas İl Milli Eğitim Müdürlüğüne bağlı 16 YİBO ile sınırlıdır. Bu çalışmanın veri toplama süreci 2008 Güz dönemi-2009 Bahar dönemi ile sinırlidir.

\section{Varsayım}

$\mathrm{Bu}$ araştırmada, öğrencilerin içinde yaşadıkları mekânlara dair algılarını gerçeğe uygun olarak yansıttıkları varsayılmaktadır.

\section{Kavramsal Çerçeve}

Eğitimbilimi alanyazın taramasında; eğitim/okul ortamlarının genellikle bürokratik, öğretmen ve/veya yönetici merkezli (Akar ve Sadık, 2003; Başar, 2000; Çınkır, 1996; Dönmez, 2008; Ersoy 2005; Gömleksiz vd. 2008; Güven ve Karataş, 2004; Özer ve Dönmez, 2007; Ünal, Öztürk ve Gürdal, 2000; Yaman, 2006; Yılmaz ve Bulut, 2002; Yurtal, 2007) olarak düzenlendiği 
belirtilmiştir. Öğrencilerin mekânsal algılamalarına yönelik çalışmaların azlığ dikkati çekmektedir. Oysa eğitim ortamlarının fiziksel koşullarının, öğrencinin gelişimsel özelliklerine/gereksinimlerine göre düzenlenmesi gerekmektedir. Özellikle YİBO'larda öğrenim gören öğrenciler için okulun eğitimsel, sosyal ve duyuşsal yaşantılarının ortak yaşam alanı olması bu konunun önemini arttırmaktadır.

Çevresel Psikoloji çevrenin - özellikle fiziksel çevrenin - insan davranışları ve deneyimleri üzerinde çeşitli ve önemli etkileri olduğuna dikkat çeker (Gürkaynak, 1988). Çevresel Psikolojinin gürültü, kalabalık, kişisel alan vb. kavramlarına, binaların ve mimari tasarımların insan-çevre ilişkileri üzerindeki etkilerine yer veren (Freeedman vd., 1989; İmamoğlu, 1997) çalışmalar, az ve çok çocuklu ailelerden gelen kız ya da erkek çocukların davranış farklılıklarının çevresel etmenlerle ilişkisini inceleyen (Güçyılmaz, 1983) araştırma, ev kadınlarının davranış alanlarını doğal/ev ortamları ve yaşam alanları içinde incelemeyi amaçlayan Etkinlik Sınırı Araştırması (Karaküçük, 1999) Türkçe alanyazında yapılmış bazı akademik çalışmalardır. Kurumsal boyutta ise, Türk ailesinin yaşadığ mekânlara/konutlara ilişkin kavramsal ve davranışsal sorunların incelendiği (Başbakanlık AABK, 1999) proje, örnek verilebilir.

Mimarlık alanında ilgili yayın ve araştırmalar da bu araştırmanın kuramsal kapsamında yer almıştır. Eğitim sistemimizde formal eğitimin büyük bölümünün okullarda gerçekleştiği dikkate alınırsa okulun mimari özelliklerinin öğrenme/öğretme süreçlerini etkileyeceği kuşkusuzdur. Mimarlık alanında, kullanıcı algısını/memnuniyetini dikkate alan araştırmalar (Başkan ve Sözen, 2006; Çınar, Çizmeci ve Akdemir, 2007; Dinç ve Onat, 2002; Edgü ve Ünlü, 2003; Günal ve Esin, 2007; Kelekçi ve Berköz, 2006; Manav ve Küçükdoğu, 2006; Yıldırım vd. 2007; Yüksel, 2005) son yıllarda yaygınlaşmıştır. Bu yaklaşımı Eğitimbilimlerine de taşıyarak, bu iki alanın işbirliği içinde eğitim ortamlarının kullanıcıları olan öğrenci görüşlerine/algılarına yönelik araştırmaların gerekliliği ortaya çıkmaktadır.

\section{YÖNTEM}

$\mathrm{Bu}$ çalışmada araştırma deseni olarak durum çalışması seçilmiştir. Nicel ve nitel yöntemleri birlikte kullanma olanağı verdiği, bütüncül bir yaklaşım içerdiği, birden fazla veri toplama tekniği kullanarak veri çeşitliliği sağladığı için bu araştırma deseni tercih edilmiştir (Yıldırım ve Şimşek, 2005:77). Araştırmada, nicel yaklaşımla anket tekniği, nitel yaklaşımla doküman incelemesi, gözlem (mekanik) ve odak grup görüşmesi teknikleri kullanılmıştır. 


\section{Araştırma Deseni}

\section{DOKÜMAN İNCELEMESI}

TSE-TS 9518 ve TS-12860 standartlarının ve YİBO'larda pansiyon günlük zaman çizelgesinin incelenmesi

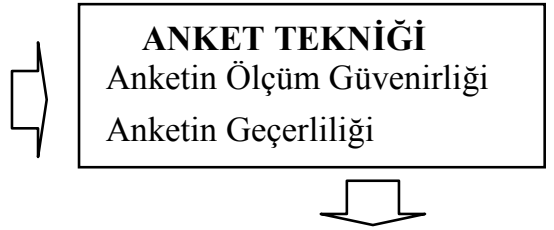

ANKET VERILERININ ÇÖZÜMLENMESI

YİBO'larda mekânsal memnuniyetsizlik yaratan sorunların ve bu sorunların en çok görüldüğ̈̈ YIBBO'lardan nitel çalışma için örneklemin belirlenmesi (Yüzde, Ki-Kare analizi, Pearson Ki Kare analizi)

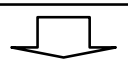

NITEL ARAŞTIRMA

Odak grup görüşmesi

Metin içerik analizi

Kodlamaların yapılması

Kodların sınıflandırılması

Temaların oluşturulması

Modellerin oluşturulması
Mekanik gözlem

(Fotoğraf çekimi)

Bilgisayara aktarılması

Görüntü içerik analizi

Kodlamaların yapılması

Metin içerik analizi-görüntü içerik analizi sonuçlarının birlikte açıklanıp yorumlanması

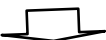

Açıklamaların ve yorumlamaların sonucu kavramsal çerçeveye ulaşılması

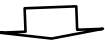

Kavramsal çerçeveye ilișkin modele ulașılması

YİBO’ların Fiziksel/Mekânsal Koşullarına İlişskin Memnuniyet Düzeyi Anketi

$\mathrm{Bu}$ araştırmada anket çalışmasının gereği, tüm çalışma grubuna (Sivas ilindeki tüm YİBO'lara) uygulanarak, nitel çalışma öncesi bu okulların fiziksel/mekânsal sorunlarının saptanması ve bu sorunların hangi YİBO'larda daha sık görüldügünün saptanması amacıyla kullanılmıştır.

Anket formunu hazırlamak için öncelikle literatür çalışması yapılmıştır. Sonra derslik, yatakhane ve bahçenin fiziksel/mekânsal koşullarının hangi 
özelliklere sahip olduğu belirlenmiştir. Daha sonra da bu koşullara ilişkin öğrencilerin memnuniyet düzeylerini soran maddeler oluşturulmuştur.

İç mekânlar-Derslik/Yatakhane

boyutunda:

- Okul içindeki yeri/ulaşımı,

- Boyut (büyüklük/küçüklük, hacim)

- Öğrenci sayısı (kalabalıklık/rahatlık),

- Ses, gürültü ve sakinlik durumu,

- Isı, havalandırma ve koku özellikleri,

- Işık durumu (aydınlık, karanlık, loşluk)

- Genel görünümü ve duvar rengi,

- Eşya ve araç gereç düzeni,

- Derslikteki/yatakhanedeki sıranın/yatağın yeri ve rahat olup olmamas1,

- Dersliğin temizlik, güvenlik durumu.
D1ş mekân-Bahçe boyutunda:

- Okul içindeki yeri/ulaşımı,

- Boyut (büyüklük/ küçüklük) ve zemin (toprak, beton vb.) uygunluğu

- Öğrenci sayıs1/dolaşım uygunluğu,

- Ses, gürültü ve sakinlik özellikleri,

- Koku, 1 şı ve aydınlatma özellikleri,

- Çim, ağaç, çiçek vb. görünümü,

- Donanımı ve araç gereç düzeni,

- Oturma/dinlenme yeri,

- Bakımı ve temizliği,

- Korunaklı ve güvenli olma durumu.

$\mathrm{Bu}$ maddeler uyarınca, öğrencilerin fiziksel koşullara ilişkin memnuniyet düzeylerini belirlemeye yarayan sorularla, "YİBO'ların fiziksel/mekânsal koşullarına ilişkin memnuniyet düzeyi" anketi oluşturulmuştur.

Sınıf ve yatakhanenin fiziksel/mekânsal koşullarına ilişkin 11 alt boyuta ait 28 madde hazırlanmıştır. Maddelerin dil ve anlatım uygunluğu için 4 Türkçe öğretmeninin görüşü alınmıştır. Pilot uygulama yapılarak YİBO 6, 7, ve 8. sinıf öğrencilerine ilk anket uygulanmıştır. Sonuçta, uzun süre YİBO'da yaşamaları ve anket doldurma düzeylerinin yüksek olması sebebiyle 8. sınıf öğrencileri örneklem grubu olarak seçilmiştir. Uzman görüşü alınarak, ankette her bir alt boyutta en çok cevap verilen maddeler seçilmiş, sınıf ve yatakhane için fiziksel/mekânsal memnuniyeti sorgulayan 11 özellik için 15 madde belirlenmiştir. Aynı yaklaşımla bahçeye ilişkin 11 özellik için 13 madde belirlenmiştir. Başka bir YİBO'da 8. sınıf öğrencilerine anketin son hali uygulanmış ve cevaplanma yüzdesinin \% 99 olduğu görülmüştür. $\mathrm{Bu}$ bağlamda anket formunun kapsam geçerliliği çalışmaları tamamlanmıştır.

\section{Anketin Ölçüm Güvenirliği}

$\mathrm{Bu}$ aşamada, anketin hangi tür ölçüm aracı olduğu ve hangi ölçüm düzeyi ile çalışma yapılacağı belirlenmiştir. Anket formunda, her bir maddenin fiziksel/mekânsal koşullara ait bir özelliği sorgulaması ve "memnunum", “orta düzeyde memnunum" ve "memnun değilim" 
seçeneklerini içermesi, anketin likert tipi maddelerin oluşturduğu tek göstergeli ölçek türü olduğunu göstermektedir. Tek göstergeli ölçüm araçlarında güvenirlilik; test yeniden test yöntemiyle sağlanmaktadır (Şencan, 2005). Bu araştırmada anket maddeleri sıralı ölçek olarak değerlendirilmiş, güvenirlik analizi ve veri analizleri buna göre yapılmıştır.

Eğer sorular, sıralama ölçeği şeklinde ise, birey ve soru farklılıklarının analizi için Friedman Ki-Kare testi uygulanır (Ergün,1995; Akgül ve Çevik, 2003). Bu çalışmada kullanılacak ölçek türünün özelliği nedeniyle güvenirlilik Friedman Ki-Kare testi ile analiz edilmiştir. Test yeniden test yöntemiyle sağlanan güvenirlilik analizinde farklı zamanlarda aynı gruba uygulanan anket maddeleri arasında fark olmaması beklenir. Aralarında anlamlı fark olan $(\mathrm{p}<, 05)$ anket maddeleri çıkarılmıştır.

Tablo 1. İlk anketle son anketin dersliklerin fiziksel/mekânsal koşullarına ilişkin ögrenci memnuniyet düzeyinin alt boyutlarını oluşturan maddelerinin karşıllaştırılması

\begin{tabular}{|c|c|c|}
\hline $\begin{array}{c}\text { Dersliklerin Fiziksel/Mekânsal Koşullarına İlişkin Öğrenci } \\
\text { Memnuniyet Düzeyi ile İlgili Maddeler }\end{array}$ & $\begin{array}{c}\text { Pearson } \\
\text { Ki-Kare } \\
\text { Anlamlılık } \\
\text { Değeri }\end{array}$ & $\begin{array}{c}\text { Friedman } \\
\text { Ki-Kare } \\
\text { Anlamlılık } \\
\text { Değeri }\end{array}$ \\
\hline Dersliğin okul içindeki yeri/ulaşımı &, 416 &, 857 \\
\hline Dersliğin boyutları, büyüklük/ küçüklük, hacim & 390 & 884 \\
\hline Dersliğin ögrenci sayısı kalabalık/rahatlık durumu & 707 & 273 \\
\hline Dersliğin ses, gürültü ve sakinlik durumu & 431 & 131 \\
\hline Dersliğin 1sıs1 ile ilgili durum & 456 & 814 \\
\hline Dersliğin havalandırması ile ilgili durum & 358 & 159 \\
\hline Dersliğin kokusu ile ilgili durum & 249 & 292 \\
\hline Dersliğin ışık (aydınlık, karanlık, loşluk) durumu &, 534 &, 590 \\
\hline Dersliğin genel görünümü &, 731 & 279 \\
\hline Dersliğin duvar rengi &, 957 & 485 \\
\hline Dersliğin eşya ve araç gereç düzeni & 609 & 376 \\
\hline Derslikte sıranızın yeri &, 425 & 210 \\
\hline Derslikte siranın rahat olup olmaması durumu & 393 & 123 \\
\hline Dersliğin temizliği & 207 & 670 \\
\hline Dersliğin sağlamlık, güvenlik durumu & 857 & 691 \\
\hline
\end{tabular}

Tabloda 1'de görüldüğü gibi, dersliğin fiziksel/mekânsal koşullarına ilişkin memnuniyet düzeyini belirlemek üzere oluşturulan anketin, test-tekrar test uygulaması sonucunda ortaya çıkan Pearson Ki-Kare ve Friedman KiKare sonuçları, gruplar arasında anlamlı bir fark bulunmadığını $(\mathrm{P}>.05)$ göstermektedir.

Tabloda 2'de görüldüğü gibi, yatakhanenin fiziksel/mekânsal koşullarına ilişkin memnuniyet düzeyini belirlemek üzere oluşturulan anketin, test-tekrar test uygulaması sonucunda ortaya çıan Pearson Ki-Kare ve Friedman Ki-Kare sonuçları, gruplar arasında anlamlı bir fark bulunmadığını ( $\mathrm{P}>$.05) göstermektedir. 
Tablo 2. Illk anketle son anketin yatakhanenin fiziksel/mekânsal koşullarına iliş̧kin ögrenci memnuniyet düzeyinin alt boyutlarını oluşturan maddelerinin karşılaş̧tırılması

\begin{tabular}{lcc}
\hline Yatakhanelerin Fiziksel/Mekânsal Koşullarına İlişkin & $\begin{array}{c}\text { Pearson } \\
\text { Ki-Kare } \\
\text { Öğrenci Memnuniyet Düzeyi ile İlgili Maddeler } \\
\text { Anlamlılık } \\
\text { Değeri }\end{array}$ & $\begin{array}{c}\text { Friedman } \\
\text { Ki-Kare } \\
\text { Anlamlılık } \\
\text { Değeri }\end{array}$ \\
\hline Yatakhanenin okul içindeki yeri/ulaşımı &, 310 &, 343 \\
Yatakhane boyutları, büyüklük/ küçüklük, hacim &, 433 &, 502 \\
Yatakhane öğrenci sayısı, kalabalık/rahatlık durumu &, 878 &, 419 \\
Yatakhanenin ses, gürültü ve sakinlik durumu &, 275 &, 100 \\
Yatakhanenin 1sısı ile ilgili durum &, 261 &, 162 \\
Yatakhanenin havalandırması ile ilgili durum &, 303 &, 069 \\
Yatakhanenin kokusu ile ilgili durum &, 248 &, 106 \\
Yatakhanenin 1şık ( aydınlık, karanlık, loşluk) durumu &, 779 &, 901 \\
Yatakhanenin genel görünümü &, 517 &, 153 \\
Yatakhanenin duvar rengi &, 409 &, 518 \\
Yatakhanenin eşya ve araç gereç düzeni &, 365 &, 159 \\
Yatakhanede yatağınızın yeri &, 756 &, 225 \\
Yatakhanede yatağınızın rahat olup olmaması &, 594 &, 264 \\
Yatakhanenin temizliği &, 234 &, 077 \\
Yatakhanenin sağlamlık, güvenlik durumu &, 514 &, 722 \\
\hline
\end{tabular}

Tablo 3. Illk anketle son anketin bahçenin fiziksel/mekânsal koşullarına ilişkin ögrenci memnuniyet düzeyinin alt boyutlarını oluşturan maddelerinin

\begin{tabular}{|c|c|c|}
\hline $\begin{array}{l}\text { Bahçelerin Fiziksel/Mekânsal Koşullarına İlişkin Öğrenci } \\
\text { Memnuniyet Düzeyi ile İlgili Maddeler }\end{array}$ & $\begin{array}{l}\text { Pearson } \\
\text { Ki-Kare } \\
\text { Anlamlık } \\
\text { Değeri } \\
\end{array}$ & $\begin{array}{c}\text { Friedman } \\
\text { Ki-Kare } \\
\text { Anlamlılık } \\
\text { Değeri } \\
\end{array}$ \\
\hline Bahçenin okul içindeki yeri/ulaşımı &, 689 &, 386 \\
\hline Bahçenin boyut (büyüklük/ küçüklük vb.) durumu & ,295 &, 686 \\
\hline Bahçe zemininin (toprak, beton vb.) uygunluk durumu & ,978 & 1,000 \\
\hline Bahçenin öğrenci sayısına/dolaşımına uygunluk durumu & ,286 & ,383 \\
\hline Bahçenin ses, gürültü ve sakinlik durumu & ,474 & ,345 \\
\hline Bahçenin kokuyla ilgili durumu &, 548 & ,484 \\
\hline Bahçenin güneş görme durumu & 464 & 1,000 \\
\hline Bahçenin gece aydınlatması &, 273 &, 083 \\
\hline Bahçenin çim, ağaç, çiçek vb. görünümü & ,287 & ,258 \\
\hline Bahçe donanımı ve araç gereç düzeni &, 736 &, 340 \\
\hline Bahçedeki oturma/dinlenme yeri & ,342 &, 118 \\
\hline Bahçenin bakımı ve temizliği & ,922 & ,446 \\
\hline Bahçenin korunaklı ve güvenli olma durumu & ,601 & ,205 \\
\hline
\end{tabular}

Tabloda 1, 2 ve 3'te görüldüğü gibi, dersliğin, yatakhanenin ve bahçenin fiziksel/mekânsal koşullarına ilişkin memnuniyet düzeylerini belirlemek üzere oluşturulan anketin, test-tekrar test uygulaması sonucunda 
ortaya çıkan Pearson Ki-Kare ve Friedman Ki-Kare sonuçları, farklı zamanlarda ayn 1 gruplara uygulanan anketin maddeleri arasında anlamlı bir fark bulunmadığını göstermektedir. Bulunan tüm anlamlılık değerleri $\mathrm{p}>$ ,05'ten büyük bulunmuştur. Bu durum anketimizin ölçüm güvenilirliğinin olduğunu göstermektedir.

\section{Anket Verilerinin Çözümlenmesi}

Anket formlarından elde edilen sıralama ölçeği verileri SPSS 16 paket programına işlenmiş yüzdelik oranları ve Ki-Kare tekniğiyle analiz edilmiştir. YIBBO'larda derslik, yatakhane ve bahçeye ilişkin genel fiziksel/mekânsal sorunların yüzdelik oranları belirlenmiştir. Daha sonra bu sorunların hangi okullarda daha fazla görüldüğünü tespit etmek için Ki- Kare tekniği kullanılmıştır. Ki-Kare testi iki sınıflamalı değişkenin düzeylerine göre oluşan düzeneklerde gözlenen sayılarla-değerlerle, beklenen sayıların değerlerinin birbirlerinden anlamlı bir farklılık gösterip göstermediğini test eder (Büyüköztürk, 2008: 148). Analizde beklenen değeri 5'ten küçük gözenek sayılarının, toplam gözenek sayısının \% 20 'sini aştı̆̆ görüldüğünden anlamlılık testine ilişkin yorumlar yapılmamış (Büyüköztürk, 2008:153) fakat yorumlar çapraz tablo üzerinden sadece frekans ve yüzdeler kullanılarak yapılmıştır (Büyüköztürk 2008: 149). Çapraz tablo herhangi bir konuyla ilgili olarak sınıflama ya da sıralama ölçeğinde belirlenen görüşlerin, sınıflamalı bir değişkene göre oluşan alt gruplar bakımından genel olarak incelenmesi olanağı sunar (Büyüköztürk, 2008:27).

\section{Kullanılan Nitel Teknikler (Odak Grup Görüşmesi ve Mekanik Gözlem)}

Ekiz (2003) hiçbir metodun, her konuyu tek başına güçlü bir biçimde inceleyemeyeceğini belirtmiştir. Nicel ve nitel araştırma yöntemleri uzun erimli bir çalışmanın farklı aşamalarında kullanılabilmektedir. Punch (2005) iki yaklaşımın güçlü yanlarından faydalanarak, zayıf yönlerini telafi edebildiklerini ve nicel araştırmanın nitel araştırmayı kolaylaştırdığını vurgulamaktadır. Bu çalışmada her iki yaklaşımdan çeşitli teknikler bir arada kullanılmıştır.

Araştırmanın bu bölümünde, nitel araştırma yöntemlerinden odak grup görüşmesi ve mekanik gözlem olarak adlandırılan fotoğraf çekimi teknikleri uygulanacaktır. YİBO'larda dersliklere, yatakhanelere ve bahçelere ilişkin memnuniyetsizlik yaratan sorunların nedenlerini araştırmak için her bir mekânsal birimle ilgili dörder odak grup görüşmesi yapılmıştır. 
Tablo 4. Derslik, yatakhane ve bahçelerle ilişkin Odak Grup görüşmesi ve gruplardaki ögrenci sayıları

\begin{tabular}{|c|c|c|c|}
\hline & $\frac{\text { Derslik }}{\text { Odak G Sayı }}$ (Öğrc.sayı) & $\frac{\text { Yatakhane }}{\text { Odak G Sayısı (Öğrc.sayı) }}$ & $\frac{\text { Bahçe }}{\text { Odak G Sayı(Öğrc.sayı) }}$ \\
\hline YİBO2 & $\mathbf{2}(8+7)$ & $\mathbf{2}(8+7)$ & $2(8+7)$ \\
\hline YİBO3 & $2(9+8)$ & $1(8)$ & $2(9+8)$ \\
\hline YİBO10 & - & $1(7)$ & - \\
\hline
\end{tabular}

Nitel araştırma, kuram oluşturmayı temel alan bir anlayışla sosyal olguları bağlı bulundukları çevre içerisinde araştırmayı ve anlamayı ön plana alan bir yaklaşımdır. Glaser, bu tanımda kuram oluşturma, toplanan verilerden yola çıkarak daha önceden bilinmeyen bir takım sonuçları birbiri ile ilişkisi içinde açıklayan bir modelleme çalışması anlamına geldiğini belirtmektedir (Akt. Yıldırım ve Şimşek, 2005). Çalışmanın bu aşamasında, YİBO öğrencilerinin yaşadıkları çevreyle (eğitim mekânları) etkileşimlerinin incelenmesi amaçlandığı için ve kuramsal uygunluk sağlaması nedeniyle nitel yöntemler kullanılmıştır.

Çalışmada örneklem olarak seçilen YİBO'larda, rasgele seçimle, sekizinci sınıf öğrencileriyle odak grup görüşmeleri yapılmıştır. Yıldırım ve Şimşek (2005), Patton'dan aktararak, bu yöntemde amaç; insanların kendi görüşlerini dikkate alarak özgürce ifade ettikleri sosyal bir içerikten yüksek nitelikli veri elde etmek olduğunu belirtir. Bu çalışmada odak grup görüşmesinin tercih edilmesinin nedeni, anket çalışmasından elde edilen sonuçların nedenlerini açıklayıcı verilere ulaşmak amacıdır.

Nitel görüşme sorularının anlaşılırlığı, Türkçe öğretmenleri ve bir Eğitim Bilimleri uzmanıyla görüşülüp kontrol edilmiş ve YİBO öğrencileriyle kendi ortamlarında gerçekleştirilen görüşmelerin ses kayıtları yapılmıştır. Belirlenen okullara gidilip daha önce ankete katılan öğrenciler arasından rastlantısal olarak seçilen öğrencilerle tanışılıp, yapılan çalışma hakkında bilgi verilmiş gönüllülük esasına dikkat edilmiştir. Her bölüme ait sorular öğrenciler tarafından sırayla cevaplandırılmış ve görüşme süreci öğrencilerin ekleyeceği bilgiler olmadığı ana kadar devam etmiştir. Görüşmelerde adı geçen mekânsal birimlerin fotoğrafları çekilmiştir. Ses kayıtları ve fotoğraflar bilgisayar ortamına aktarılmış, düzenlenip analiz sürecine geçilmiş̧ir.

Verilerin çözümlenmesi, içerik analizi yöntemi ile yapılmıştır. $\mathrm{Bu}$ analiz sürecinde QSR Nvivo8 nitel araştırma programı kullanılmıştır. İçerik analizinde temelde yapılan işlem birbirine benzeyen verileri belirli kavramlar ve temalar çerçevesinde bir araya getirmek ve bunları okuyucunun anlayabileceği bir biçimde düzenleyerek yorumlamaktır (Yıldırım ve Şimşek, 2005). 
Görüşme kayıtlarını içeren metinler üzerinde kodlamalar yapılarak içerik analizi uygulanmıştır. Gibbs, "Kodlama özsel bir süreçtir. Araştırmanın üstünlüğü büyük oranda kodlamanın üstünlügüne bağlıdır" demektedir (Akt. Kuş, 2006: 86). Flick’e göre, kodlama süreci aynı zamanda "verilerden teorilerin inşa edildiği temel süreç"tir (Akt. Kuş, 2006: 48). Gibbs'e, göre ise kodlama aynı teorik ya da betimsel fikri örneklendiren metin parçalarını ya da veri parçalarını (ör: bir resmin parçalarını) belirleme sürecidir (Akt. Kuş, 2006). Görüşme kayıtlarının bu şekilde kodlanıp, temalaştırılması içerik analizinin yapısına uygundur. Bu bağlamda kodlar ilgili mekânsal sorunların/özelliklerin başlıkları altında sınıflanmıştır. "ïlk aşamada ortaya çıkan kodlardan yola çıkarak verileri genel düzeyde açıklayabilen ve kodları belirli kategoriler altında toplayabilen temaların bulunması gerekmektedir. Temaların bulunması için kodlar bir araya getirilir ve incelenir. Kodlar arasındaki ortak yönler bulunmaya çalışılır. Bu bir anlamda tematik kodlama işlemidir ve toplanan verilerin kodlar aracılığı ile kategorize edilmesidir" (Yıldırım ve Şimşek, 2005). Bu kodlama işlemleri QSR NVIVO 8 programında gerçekleştirilmiştir. Tema başlıkları altında sınıflanan kodlar tablolaştırılmıştır.

QSR Nvivo 8'de veriler arasındaki bağlantıları, ilişkileri görselleştirmek üzere çeşitli modeller oluşturma imkânı vardır. Miles ve Huberman, nitel araştırma metodolojisi içinde model hazırlamayı önemsemekte ve önermektedir ( Akt. Kuş, 2006). İlgili programda verilerin kodlanıp temalar halinde getirilmesinin ardından analiz sonuçları modeller olarak ifade edilmiştir. Bu modeller üzerinden yorumlar yapılmıştır. Aşağıda bu modellerden biri örnek olarak verilmiştir.

Mekanik gözlem, fotoğraf makinesi, video kamera gibi araçlar kullanılarak davranış ve sosyal ortama ilişkin gözlemlerin kayıt altına alınmasıdır (Baş ve Akturan, 2008). Bu yöntemle görüşme yapılan YİBO'ların eğitim mekânlarının fotoğrafları çekilmiş ve fotoğrafların analizi QSR Nvivo 8 programı ile yapılmıştır. Kuş (2009), fotoğrafların daha detaylı analiz edilebildiğini, fotoğraflardaki belli bölümlerin kategorileştirilebildiğini ve bu sürecin geri dönülerek kontrol edilmesinin de çok daha kolay ve hızlı olduğunu belirtmiştir. Fotoğraf üzerinde yapılan kodlamalar programdan çıktı olarak alınmış ve analiz süreci tamamlanmıştır. 


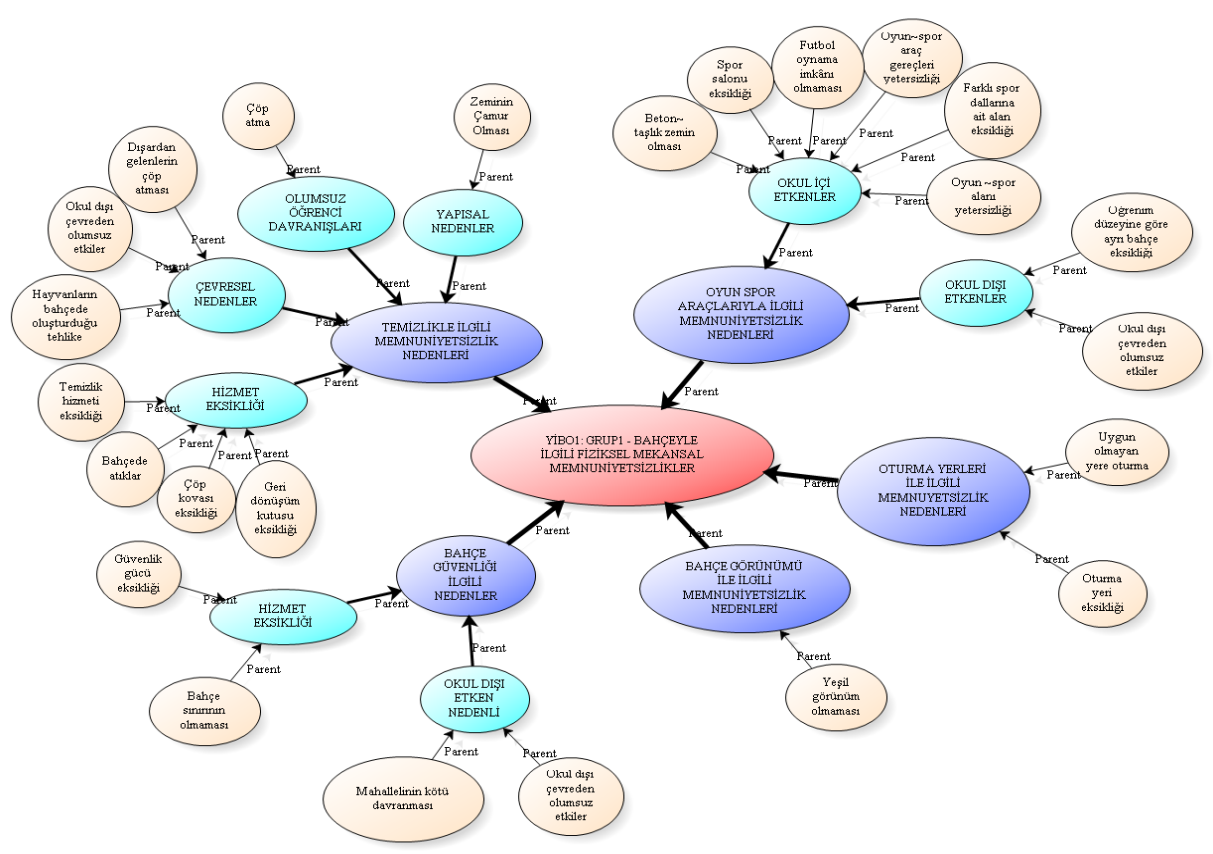

Model 1. Sürecin QSR NVIVO 8 programında gerçekleştirilip modellerin oluşturulması

Araştırmanın nitel bulgularına, YİBO'ların incelenen birimleriyle ilgili toplanan tüm verilerin bir arada değerlendirilip yorumlanmasıyla ulaşılmıştır. Bu aşamada yorumlayıcı bir analiz süreci izlenmiştir. Örneğin; YİBO 2'de öncelikle derslikle ilgili olarak saptanan fiziksel/mekânsal sorunlar ele alınmış ve temaları içeren tablolar halinde ve aynı bulgular QSR Nvivo 8 programı çıktısı olan modeller şeklinde görselleştirilmiştir. Daha sonra yine dersliklere ilişkin fotoğraf analizleri (mekanik gözlem) sonucunda ortaya çıkan kodlar ele alınmıştır. Başka deyişle, YIBO2'in dersliklerine ilişkin yapılmış olan iki odak grup görüşmesinin analiz sonuçları ile mekanik gözlem sonucu ortaya çıkan fotoğraf analizlerinin sonuçları bir arada değerlendirilmiştir. Aynı işlemler yatakhaneler ve bahçeler için de yapılmıştır. 


\section{BULGULAR}

Araştırmanın birinci alt problemine ilişkin olarak; Türk Standartları Kurallarına göre eğitim öğretim alanlarında bulunması gereken mekânlar Tablo 5'te gösterilmiştir:

Tablo 5. TS 9518-TS 12860 standartlarına göre ĕgitim ögretim alanlarında bulunması gereken birimler

\begin{tabular}{lcl}
\hline & Ĕgitim Binalarındaki Ortak Mekânlar \\
\hline - Müdür odas1 & -Psikolog odas1 & - Yayın-memur odası \\
- Müdür yrd odas1 & -Muayene odas1 & - Ders aletleri odas1 \\
- Sekreter odas1 & -Ziyaretçi odas1 & - Duş mahali \\
- Öğretmenler odas1 & -Fotokopi odası & - Genel mekân ve mahaller \\
- Hizmetli odas1 & - Kışlı teneffüshane & - Kapalı garaj \\
\hline
\end{tabular}

\begin{tabular}{|c|c|c|c|}
\hline \multicolumn{4}{|c|}{ İlköğretim Okullarındaki Mekânlar } \\
\hline İdare & Eğitim & Yatakhane & Mutfak \\
\hline Rehberlik odas1 & Okul önc. eğit. böl. & -Kı̈ öğrenci & - Giriş \\
\hline Zümre öğr. odası & -Oyun odasi & yatakhanesi & - Tartı mahali \\
\hline Kat öğretmeni odası & -8 yıllık eğit. böl. & - Erkek öğrenci & - Umumi depo \\
\hline Rehberlik servisi & Derslik & yatakhanesi & - Soğuk depo \\
\hline Okul aile birliği od. & - Özel derslik & - Personel ytk. & - Hazırlık mahali \\
\hline Bilgi islem merkezi & - Görsel derslik & - Belletici öğretmen & - Pisirme mahali \\
\hline Revir & - Resim dersliği & odas1 & - Soğuk yiyecekler \\
\hline Çok amaçlı salon & - Müzik dersliği & - Oturma salonu & - Hamur isleri \\
\hline Ortak mekânlar & Atölye & - Kantin & hazırlama mahali \\
\hline Kütüphane & - İş teknik atölyesi & - Çamaşırhane & - Bulaşık yıkama \\
\hline Kantin & - Cilt atölyesi & - Emanet esya depo. & mahali \\
\hline Spor salonu & - Ahsap atölyesi & - Berber & - Mutfak sefi \\
\hline Acık alanlar & - Metal atölyesi & - Lostra & - Personel \\
\hline Rehberlik odas 1 & Laboratuar & - Temiz camasir & Yemekhanesi \\
\hline Zümre öğr. odas1 & - Fizik laboratuarı & deposu & - Personel WC. \\
\hline Kat öğretmeni odası & - Kimya laboratuarı & - Kat çamaşır odası & lavabo, duș \\
\hline Rehberlik servisi & - Biyoloji laboratuarı & & - Çöp odas1 \\
\hline Okul aile birliği ve & -Yabanci dil ve & & \\
\hline koruma dern. odas1 & bilgisayar lab & & \\
\hline
\end{tabular}

Doküman incelemesi sonucunda; Sivas ilinde eğitim veren YİBO'larda öğrencilerin en çok zaman geçirdikleri okul içi/dışı mekânların; iç mekân olarak derslikler ve yatakhaneler, dıș mekân olarak bahçe olduğu ortaya çıkmıştır. Böylece hangi yaşam alanlarıyla ilgili "Fiziksel/Mekânsal memnuniyet düzeyi anketi" hazırlanacağ hakkında ön hazırlık yapılmıştır.

Araştırmanın ikinci alt problemine ait bulgular Tablo 6'da özetlenmiştir: 
Tablo 6. YIBO'larda günlük zaman çizelgesi

\begin{tabular}{llll}
\hline Saat & Yapılacak İşlem & Saat & Yapılacak İşlem \\
\hline $06.00-06.10$ & Uyanma-temizlik & $17.00-17.30$ & Dinlenme \\
$06.10-07.15$ & Sabah etüdü & $17.30-18.00$ & Yoklama \\
$07.15-07.50$ & Kahvaltı & $18.00-18.50$ & Akşam yemeği \\
$07.50-08.15$ & Derse hazırlık & $18.50-19.00$ & Temizlik \\
$08.20-12.00$ & Dersler & $19.00-19.40$ & Birinci etüt \\
$12.00-13.00$ & Öğle yemeği & $19.40-19.50$ & Teneffüs \\
$13.00-13.30$ & Dinlenme & $19.50-20.30$ & İkinci etüt \\
$13.30-15.00$ & Dersler & $20.30-21.00$ & Yatma hazırlıkları \\
$15.15-17.00$ & Ders dışı sosyal etkinlikler & $21.00-21.30$ & Yoklama \\
\hline
\end{tabular}

Araştırmanın üçüncü alt problemine ilişkin olarak YİBO öğrencilerinin, incelenen eğitim mekânlarının fiziksel/mekânsal koşullarına ilişkin memnuniyet düzeyleri Tablo 7'de gösterilmiştir:

Tablo 7. Dersliklerin fiziksel/mekânsal koşullarına ilişkin öğrenci memnuniyet düzeylerine ait yüzde oranlarl

\begin{tabular}{lccc}
\hline $\begin{array}{l}\text { Dersliklerin Fiziksel/Mekânsal Koşullarına İlişkin } \\
\text { Öğrenci Memnuniyet Düzeyi }\end{array}$ & $\begin{array}{c}\text { Memnun } \\
\text { Değilim } \\
(\mathbf{\%})\end{array}$ & $\begin{array}{c}\text { Orta Düzeyde } \\
\text { Memnunum } \\
(\boldsymbol{\%})\end{array}$ & $\begin{array}{c}\text { Memnunum } \\
(\boldsymbol{\%})\end{array}$ \\
\hline Dersliğin okul içindeki yeri/ulaşımı & 8,7 & 15 & 76,3 \\
Dersliğin boyutları, büyüklük/ küçüklük, hacim & 7,8 & 27,2 & 65 \\
Dersliğin öğrenci sayısı kalabalı/rahatlık durumu & 16,6 & 17,2 & 66,2 \\
Dersliğin ses, gürültü ve sakinlik durumu & $\mathbf{3 9 , 9}$ & 33,1 & 27 \\
Dersliğin 1sıs1 ile ilgili durum & 19,2 & 35,9 & 44,9 \\
Dersliğin havalandırması ile ilgili durum & 22 & 35,5 & 42,5 \\
Dersliğin kokusu ile ilgili durum & $\mathbf{3 5 , 2}$ & 36,6 & 28,2 \\
Dersliğin 1ş1k (aydı̈lık, karanlık, loşluk) durumu & 5,2 & 17,0 & 77,9 \\
Dersliğin genel görünümü & 19,6 & 32,6 & 47,8 \\
Dersliğin duvar rengi & $\mathbf{2 6 , 2}$ & 25,7 & 48,1 \\
Dersliğin eşya ve araç gereç düzeni & $\mathbf{2 4 , 6}$ & 36,0 & 39,3 \\
Derslikte sıranızın yeri & 17 & 19,9 & 63,2 \\
Derslikte sıranın rahat olup olmaması durumu & 17,2 & 19,7 & 63,0 \\
Dersliğin temizliği & $\mathbf{2 7 , 8}$ & 36,3 & 35,9 \\
Dersliğin sağlamlık, güvenlik durumu & 13 & 31,5 & 55,5 \\
\hline
\end{tabular}

Tablo 7'ye bakıldığında, öğrencilerin memnuniyetsizlik düzeylerinin (dersliğe, yatakhaneye ve bahçeye ilişkin) fiziksel/mekânsal koşulların hangi özelliklerinde daha yüksek olduğu belirlenmiştir. Daha sonra söz konusu memnuniyetsizlik durumlarının çalışma grubunu oluşturan okulların hangilerinde daha çok görüldüğü bulgulanmıştır. $\mathrm{Bu}$ sonuçlar nitel çalışmanın kapsamını ortaya çıkarmıştır.

Dersliğin fiziksel/mekânsal koşullarına ilişkin sorunları belirlemek için memnuniyetsizlik oranı en yüksek özellikler seçilmiştir. Buna göre derslik 
için; ses gürültü $(\% 39,9)$, koku $(\% 35,2)$, temizlik $(\% 27,8)$ duvar rengi $(\% 26,2)$, eşya düzeni sorunları $(\% 24,6)$ nın yoğun olduğu görülmektedir.

Tablo 8. Yatakhanelerin fiziksel/mekânsal koşullarına ilişkin öğrenci memnuniyet düzeylerine ait yüzde oranları

\begin{tabular}{|c|c|c|c|}
\hline $\begin{array}{c}\text { Yatakhanelerin Fiziksel/Mekânsal Koşullarına } \\
\text { İlişkin Öğrenci Memnuniyet Düzeyi }\end{array}$ & $\begin{array}{l}\text { Memnun } \\
\text { Değilim } \\
\quad(\%)\end{array}$ & $\begin{array}{c}\text { Orta } \\
\text { Düzeyde } \\
\text { Memnunum } \\
(\%)\end{array}$ & $\begin{array}{c}\text { Memnunum } \\
(\%)\end{array}$ \\
\hline Yatakhanenin okul içindeki yeri/ulaşımı & 13,2 & 12,8 & 73,9 \\
\hline Yatakhane boyutları, büyüklük/ küçüklük, hacim & 20,8 & 23,2 & 56,0 \\
\hline Yatakhane öğrenci sayısı, kalabalıklık durumu & 16,4 & 22,3 & 61,3 \\
\hline Yatakhanenin ses, gürültü ve sakinlik durumu & 37,7 & 34,6 & 27,7 \\
\hline Yatakhanenin 1sısı ile ilgili durum & 20,1 & 29,7 & 50,2 \\
\hline Yatakhanenin havalandirması ile ilgili durum & 26,1 & 31,3 & 42,6 \\
\hline Yatakhanenin kokusu ile ilgili durum & 35,5 & 35,2 & 29,3 \\
\hline Yatakhanenin 1şık( aydınlık, karanlık) durumu & 10,1 & 17,2 & 72,7 \\
\hline Yatakhanenin genel görünümü & 18,3 & 25,2 & 56,6 \\
\hline Yatakhanenin duvar rengi & 29,3 & 21,5 & 49,3 \\
\hline Yatakhanenin eşya ve araç gereç düzeni & 20,8 & 31,8 & 47,4 \\
\hline Yatakhanede yatağınızın yeri & 14 & 17,6 & 68,3 \\
\hline Yatakhanede yatağınızın rahat olup olmaması & 12,8 & 13,6 & 73,5 \\
\hline Yatakhanenin temizliği & 17 & 31,7 & 51,4 \\
\hline Yatakhanenin sağlamlık, güvenlik durumu & 16,2 & 27 & 56,8 \\
\hline
\end{tabular}

Tablo 8'e göre, YİBO'larda yatakhanelere ilişkin memnuniyetsizlik yaratan sorunların, ses/gürültü $(37,7)$, koku $(35,5)$, duvar rengi $(29,3)$, boyut( $(20,8)$, eşya rengi ve düzeni $(20,8)$ ve *havalandırma $(26,1)$ olduğu görülmektedir.

Tablo 9: Bahçelerin fiziksel/mekânsal koşullarına iliş̧kin öğrenci memnuniyet düzeylerine ait yüzde oranlarl

\begin{tabular}{lccc}
\hline $\begin{array}{l}\text { Bahçelerin Fiziksel/Mekânsal Koşullarına } \\
\text { İlişkin Öğrenci Memnuniyet Düzeyi }\end{array}$ & $\begin{array}{c}\text { Memnun } \\
\text { Değilim } \\
(\mathbf{\%})\end{array}$ & $\begin{array}{c}\text { Orta Düzeyde } \\
\text { Memnumum } \\
(\boldsymbol{\%})\end{array}$ & $\begin{array}{c}\text { Memnunum } \\
(\boldsymbol{\%})\end{array}$ \\
\hline Bahçenin okul içindeki yeri/ulaşımı & 13,5 & 14 & 72,5 \\
Bahçenin boyut (büyüklük/ küçüklük) durumu & 18,7 & 21,3 & 60 \\
Bahçenin zeminin (toprak, beton vb.) durumu & 22,1 & 24,5 & 53,4 \\
Bahçenin öğrenci sayısına/dolaşımına uygunluğu & 22,4 & 32,6 & 45 \\
Bahçenin ses, gürülttü ve sakinlik durumu & 22,1 & 35,1 & 42,8 \\
Bahçenin kokuyla ilgili durumu & 21,1 & 25,6 & 53,4 \\
Bahçe güneş görme durumu & 10,3 & 13,1 & 76,6 \\
Bahçenin gece aydınlatması & 21,9 & 20,5 & 57,6 \\
Bahçenin çim, ağaç, çiçek vb. görünümü & $\mathbf{2 2 , 5}$ & 20,2 & 57,3 \\
Bahçe donanımı ve araç gereç düzeni & $\mathbf{3 0 , 7}$ & 25,7 & 43,6 \\
Bahçedeki oturma/dinlenme yeri & $\mathbf{3 3 , 0}$ & 23 & 44 \\
Bahçenin bakımı ve temizliği & $\mathbf{2 8 , 6}$ & 32,2 & 39,2
\end{tabular}


Tablo 9'a göre bahçe için; oturma yerleri $(\% 33,0)$, bahçe donanımı ve araç gereç düzeni $(\% 30,7)$, temizlik $(\% 28,6)$, bahçe güvenliği $(\% 23,2)$, bahçe görünümü $(\% 22,5)$ sorunları olduğu görülmektedir.

Araştırmanın nitel yönteminin gerçekleştirileceği okulları saptamak için sorunlara ilişkin memnuniyetsizlik düzeyi en fazla olan ve memnuniyetsizlik düzeyi yüzdesi genel memnuniyetsizlik düzeyi yüzdesinden daha fazla olan beş okul seçilmiştir. Memnuniyetsizlik belirtilen özelliklere sahip olma açısından listede en çok adı yinelenen YİBO'lar YİBO6 (5), YİBO2 (5) ve YİBO3 (4) olarak belirlenmiştir. Bu üç okuldan aralarında anlamlı fark olmayan YİBO2 ve YİBO3 okulları nitel çalışmalar için seçilmiştir. Seçilen okullar Tablo 10'da görülmektedir.

Tablo 10. Dersliklere ilişkin memnuniyetsizlik yaratan sorunların en sık görüldüğü okullar

\begin{tabular}{|c|c|c|c|c|c|}
\hline \multicolumn{6}{|c|}{ Dersliklere iliskin memnunivetsizlik sebepleri } \\
\hline \multirow{12}{*}{ 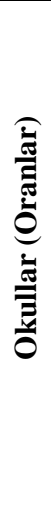 } & $\begin{array}{c}\text { Ses/Gürülttü } \\
(39,9)^{*}\end{array}$ & $\begin{array}{c}\text { Koku } \\
(35,2)^{*}\end{array}$ & $\begin{array}{c}\text { Temizlik } \\
(27,8) *\end{array}$ & $\begin{array}{c}\text { Duvar Rengi } \\
(26,2)^{*}\end{array}$ & $\begin{array}{c}\text { Derslik Düzeni } \\
(24,6) *\end{array}$ \\
\hline & YİBO2 & YİBO6 & YİBO6 & YİBO12 & YİBO6 \\
\hline & $(80,4)$ & $(69,7)$ & $(87,9)$ & $(43,9)$ & $(63,6)$ \\
\hline & YİBO6 & YİBO2 & YİBO2 & YİBO1 & YİBO4 \\
\hline & $(75,8)$ & $(66,7)$ & $(62,7)$ & $(40,4)$ & $(47,2)$ \\
\hline & YİBO3 & YİBO9 & YİBO3 & YİBO5 & YİBO2 \\
\hline & $(63,6)$ & $(62,1)$ & $(54,5)$ & $(37,8)$ & $(41,2)$ \\
\hline & YİBO13 & YİBO3 & YİO4 & YİBO2 & YİBO3 \\
\hline & $(62,5)$ & $(54,5)$ & $(41,7)$ & $(35,3)$ & $(36,4)$ \\
\hline & YİBO7 & YİBO13 & YİBO14 & YİBO10/ YİBO6 & YİBO16 \\
\hline & $(58,8)$ & $(50,0)$ & $(33,3)$ & $(33,3)$ & $(36,2)$ \\
\hline & & & & $\begin{array}{c}\text { * YİBO3 } \\
(27,3)\end{array}$ & \\
\hline
\end{tabular}

* Bu özelliğe ilişkin memnuniyetsizlik düzeyi ortalaması

Tablo 11'de görüldüğü gibi örneklemi oluşturan okullarda, memnuniyetsizlik/sorun yaratan beş fiziksel/mekânsal özellik arasında anlamlı farklılık yoktur ve memnuniyetsizlik yüzdeleri benzerlik göstermektedir. Bunun sonucunda bu iki okul nitel çalışma için seçilmiştir. 
Tablo 11. Belirlenen okulların dersliklerine ilişkin fiziksel/mekânsal sorunlar içeren özellikler ve bunlara ilişkin ögrenci memnuniyetsizlik düzeyleri

\begin{tabular}{|c|c|c|c|c|c|}
\hline \multicolumn{6}{|c|}{ Dersliklerin fiziksel/mekânsal koșullarına ilișkin öğrenci memnuniyetsizlik düzeyi } \\
\hline \multirow{3}{*}{ 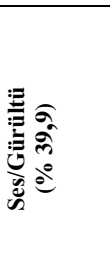 } & Okullar & $\underset{(\%)}{\substack{\text { Memnnun } \\
\text { Değilim }}}$ & $\underset{(\%)}{\text { Orta Düzeyde }}$ & $\begin{array}{c}\text { Memnunum } \\
(\%)\end{array}$ & $\begin{array}{c}\text { Pearson Ki- } \\
\text { Kare }\end{array}$ \\
\hline & YїBO2 & 80,4 & 11,8 & 7,8 & \multirow{2}{*}{, 240} \\
\hline & YївO3 & 63,6 & 27,3 & 9,1 & \\
\hline \multirow{2}{*}{ 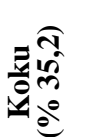 } & YїВ2 & 66,7 & 29,4 & 3,9 & \multirow[t]{2}{*}{, 511} \\
\hline & YївO3 & $\mathbf{5 4 , 5}$ & 36,4 & 9,1 & \\
\hline \multirow{2}{*}{ 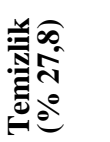 } & YїBO2 & 62,7 & 23,5 & 13,7 & \multirow{2}{*}{, 506} \\
\hline & YїBO3 & 54,5 & 36,4 & 9,1 & \\
\hline \multirow{2}{*}{ 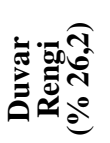 } & YїBO2 & $\mathbf{3 5 , 3}$ & 23,5 & 41,2 & \multirow[t]{2}{*}{, 169} \\
\hline & YїBO3 & 27,2 & 45,5 & 27,3 & \\
\hline \multirow{2}{*}{ 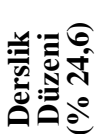 } & YїBO2 & 41,2 & 39,2 & 19,6 & \multirow{2}{*}{,917 } \\
\hline & YїBO3 & 36,4 & 40,9 & 22,7 & \\
\hline
\end{tabular}

YİBO'larda bulunan yatakhanelere ilişkin sorunların sebeplerinin araştırılabilmesi için, ilgili özelliklere ait memnuniyetsizlik düzeyi en yüksek olan ilk beş okul Ki Kare analizi sonuçlarına göre seçilmiştir.

Araştırmanın nitel yönteminin gerçekleştirileceği okulları saptamak için sorunlara ilişkin memnuniyetsizlik düzeyi en fazla olan ve memnuniyetsizlik düzeyi yüzdesi genel memnuniyetsizlik düzeyi yüzdesinden daha fazla olan beş okul yazılmıştır. Tablo 12'deki listede adı en çok geçen YİBO2 (5), YİBO3 (5) ve YİBO10 (5) YİBO'lar olarak belirlenmiştir. Bu üç okul da, aralarında anlamlı fark olmadığı için; YİBO2 ve YİBO3 ve YİBO10 okulları nitel çalışmalar için seçilmiştir. 
Tablo 12. Yatakhanelere ilişkin memnuniyetsizlik yaratan sorunların en sık görüldüğ̈̈ okullar

Yatakhaneye ilişkin memnuniyetsizlik sebepleri

\begin{tabular}{|c|c|c|c|c|c|c|}
\hline \multirow{11}{*}{ 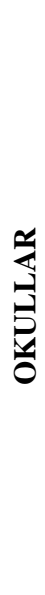 } & $\begin{array}{l}\text { Ses Düzeyi } \\
(\% \text { 37,7)* }\end{array}$ & $\begin{array}{c}\text { Koku } \\
(\% \text { 35,5)* }\end{array}$ & $\begin{array}{c}\text { Duvar Rengi } \\
(\% 29,3) *\end{array}$ & $\begin{array}{c}\text { Ytkh. Düzeni } \\
(\% 20,8)^{*}\end{array}$ & $\begin{array}{c}\text { Ytkh. Boyutu } \\
(\% 20,8)^{*}\end{array}$ & $\begin{array}{c}* * \text { Havalandirma } \\
(\% 26,1) *\end{array}$ \\
\hline & YİBO11 & YİBO2 & YİBO3 & YİBO6 & YİBO3 & YİBO2 \\
\hline & $(60,9)$ & $(56,9)$ & $(50,0)$ & $(48,1)$ & $(50,0)$ & $(41,1)$ \\
\hline & YİBO10 & YİBO3 & YİBO5 & YİBO3 & YİBO10 & YİBO6 \\
\hline & $(51,0)$ & $(54,5)$ & $(48,6)$ & $(36,4)$ & $(47,1)$ & $(39,4)$ \\
\hline & YİBO3 & YİBO6 & YİBO10 & YİBO13 & YİBO2 & YİBO12 \\
\hline & $(50,0)$ & $(54,5)$ & $(47,1)$ & $(34,4)$ & $(43,1)$ & $(36,6)$ \\
\hline & YİBO2 & YİBO10 & YİBO1 & YİBO10 & YİBO6 & YİBO13 \\
\hline & $(43,1)$ & $(49,9)$ & $(46,2)$ & $(29,4)$ & $(39,4)$ & $(34,4)$ \\
\hline & YİBO7 & YİBO13 & YİBO2 & YİBO2 & YİBO13 & YİBO9 \\
\hline & $(41,2)$ & $(50,0)$ & $(43,1)$ & $(25,5)$ & $(25,0)$ & $(31,0)$ \\
\hline
\end{tabular}

* Bu özelliğe ilişkin memnuniyetsizlik düzeyi ortalaması.

** Havalandırma özelliğiyle ilgili memnuniyetsizlik oranı yüksek olsa da, sağlıklı örneklem seçebilmek için havalandırma sorunu göz ardı edilmiştir. Bir sonraki yüksek memnuniyetsizlik yüzdesine sahip olan yatakhanenin boyut sorunu tabloya dahil edilmiştir.

Tablo 13'te görüldüğü gibi örneklemi oluşturan okullarda, memnuniyetsizlik/sorun yaratan beş fiziksel/mekânsal özellik arasında anlamlı farkl11ı yoktur ve memnuniyetsizlik yüzdeleri benzerlik göstermektedir. Bu çalışmada yapılacak nitel çalışma için sorun seçimi ve örneklem seçimi önemli olduğu için örneklemimizde farklılık yaratacak olan havalandırma sorunu göz ardı edilmiştir.

Araştırmanın nitel yönteminin gerçekleştirileceği okulları saptamak için sorunlara ilişkin memnuniyetsizlik düzeyi en fazla olan ve memnuniyetsizlik düzeyi yüzdesi genel memnuniyetsizlik düzeyi yüzdesinden daha fazla olan beş okul yazılmıştır. Tablo 14'teki listede adı en çok geçen YİBO2 (5), YİBO3 (5) ve YİBO6 (5) olarak belirlenmiştir. Bu üç okuldan aralarında anlamlı fark olmayan YİBO2 ve YİBO3 okullar nitel çalışma için seçilmiş̧ir. 
Tablo 13. Belirlenen okullarm yatakhanelerine ait sorunların memnuniyet düzeylerine iliş̧kin Pearson Ki Kare sonuçları

\begin{tabular}{|c|c|c|c|c|c|}
\hline & nelerin fizil & mekânsal & ullarına ilişkin & renci memnu & t düzeyi \\
\hline \multirow{4}{*}{ 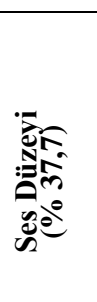 } & Okullar & $\begin{array}{l}\text { Memnun } \\
\text { Değilim } \\
(\%)\end{array}$ & $\begin{array}{c}\text { Orta Düzeyde } \\
\text { Memnunum } \\
(\%)\end{array}$ & $\underset{(\%)}{\operatorname{Memnunum}}$ & $\begin{array}{l}\text { Pearson } \\
\text { Ki-Kare }\end{array}$ \\
\hline & YївО2 & 43,1 & 33,3 & 23,5 & \multirow{3}{*}{, 121 } \\
\hline & уїоз & 50,0 & 45,5 & 4,5 & \\
\hline & YївO10 & 51,0 & 41,2 & 7,8 & \\
\hline \multirow{3}{*}{ 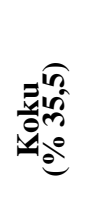 } & YївO2 & 56,9 & 29,4 & 13,7 & \multirow{3}{*}{, 740} \\
\hline & Yїо3 & 54,5 & 22,7 & 22,7 & \\
\hline & уівО10 & 49,0 & 27,5 & 23,5 & \\
\hline \multirow{3}{*}{ 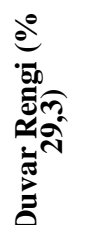 } & YївO2 & 43,1 & 23,5 & 33,3 & \multirow{3}{*}{,827 } \\
\hline & yївO3 & 50,0 & 22,7 & 27,3 & \\
\hline & үївО10 & 47,1 & 29,4 & 23,5 & \\
\hline \multirow{3}{*}{ 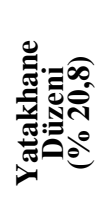 } & YївO2 & 25,5 & 45,1 & 29,4 & \multirow{3}{*}{897} \\
\hline & уїво3 & 36,4 & 36,4 & 27,3 & \\
\hline & YїBO10 & 29,4 & 39,2 & 31,4 & \\
\hline \multirow{3}{*}{ 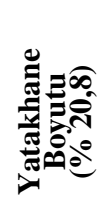 } & үївО2 & 43,1 & 11,8 & 45,1 & \multirow[t]{3}{*}{, 828} \\
\hline & YİBO3 & 50,0 & 13,6 & 36,4 & \\
\hline & YїBO10 & 47,1 & 17,6 & 35,3 & \\
\hline
\end{tabular}


Tablo 14. Bahçelere ilişkin memnuniyetsizlik yaratan sorunların en sık görüldüğ̈̈ okullar

\begin{tabular}{|c|c|c|c|c|c|}
\hline \multicolumn{6}{|c|}{ Yatakhaneye ilişkin memnuniyetsizlik sebepleri } \\
\hline \multirow{10}{*}{ 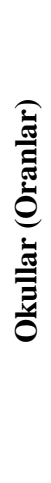 } & $\begin{array}{l}\text { Oturma/Dinlenme } \\
\text { Yeri }(\% \text { 33,0) }\end{array}$ & $\begin{array}{l}\text { Donanım } \\
(\% \text { 30,7) }\end{array}$ & $\begin{array}{c}\text { Bakım ve Temizlik } \\
(\% 28,6)\end{array}$ & $\begin{array}{l}\text { Güvenlik } \\
(\% 23,2)\end{array}$ & $\begin{array}{l}\text { Görünüm } \\
(\% \text { 22,5) }\end{array}$ \\
\hline & YİBO6 & YİBO3 & YİBO6 & $\begin{array}{l}\text { YİBO2 } \\
(667)\end{array}$ & YİBO2 \\
\hline & YİBO4 & YİBO2 & YİBO2 & YİBO6 & YİBO6 \\
\hline & $(66,7)$ & $(76,5)$ & $(68,6)$ & $(51,5)$ & $(48,5)$ \\
\hline & YİO2 & YİBO6 & YİBO3 & YİBO3 & YİBO3 \\
\hline & $(60,8)$ & $(60,6)$ & $(50,0)$ & $(50,0)$ & $(45,5)$ \\
\hline & YİO3 & YİBO11 & YİO4 & YİBO1 & YİBO4 \\
\hline & $(59,1)$ & $(41,1)$ & $(41,7)$ & $(30,8)$ & $(44,4)$ \\
\hline & YİBO11 & YİBO13 & YİBO7 & YİBO10/ & YİBO7 \\
\hline & $(41,3)$ & $(37,5)$ & $(41,2)$ & $\begin{array}{l}\text { YİBO7 } \\
(29,4)\end{array}$ & $(32,4)$ \\
\hline
\end{tabular}

Tablo 15. Belirlenen okulların bahçelerine ait sorunların memnuniyet düzeylerine ilişkin Pearson Ki-Kare sonuçları

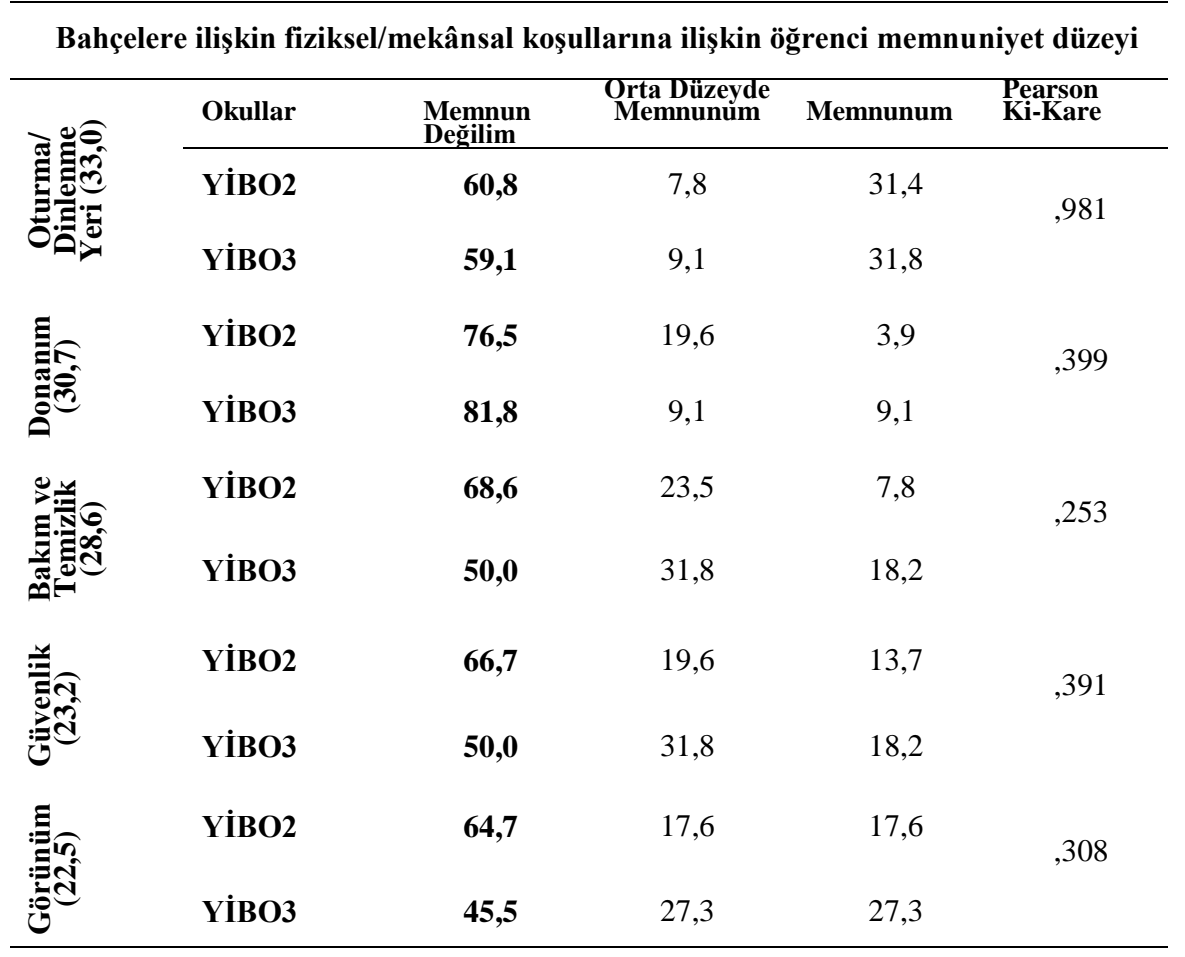


Tablo 15'te görüldüğü gibi örneklemi oluşturan okullarda, memnuniyetsizlik/sorun yaratan beş fiziksel/mekânsal özellik arasında anlamlı farklılık yoktur ve memnuniyetsizlik yüzdeleri benzerlik göstermektedir. Bunun sonucunda YIBBO2 ve YİBO3 okulları nitel çalışma için seçilmiştir.

Araştırmanın dördüncü alt problemine ilişkin olarak; nitel çalışmanın örneklemini oluşturan okullarda memnuniyetsizlik yaratan fiziksel/mekânsal koşulların nedenleri belirlenmiştir.

Dersliğe ait gürültüye/sese ilişkin memnuniyetsizlik nedenlerinin "derslik içi kaynaklı" ve "derslik dışı kaynaklı" ana temalar altında toplandığı görülmüştür. Derslik içi kaynaklı ana tema altında "yanlış sınıf düzeni" ve "olumsuz birey davranışları" temaları bulunduğu görülmüştür. Dersliğin kokusuna ilişkin memnuniyetsizlik nedenleri "derslik içi” ve "derslik dışı kaynaklı" ana temaları altında toplanmıştır. "Yanlış sınıf düzeni" ve "bireylerden kaynaklanan koku" temaları derslik içi kaynaklı ana temanın altında toplanmıştır. "Bina yapım yanlışlığı/yetersizliği", "bireylerden kaynaklanan" ve "çevreden kaynaklanan" temaları ise derslik dışı kaynaklı ana temanın altında toplanmıştır. Dersliğin temizliğine ilişkin memnuniyetsizlik nedenlerinin "çevresel nedenler", "hizmet eksikliği/yetersizliği" ve "olumsuz birey davranışları" temaları altında toplandığı bulgulanmıştır. Dersliğin duvar rengine ilişkin memnuniyetsizlik nedenleri "kişisel beğenilerle ilgili nedenler" ve "renk diş1 etkenler/sorunlar" temaları altında toplanmıştır. Dersliğin eşya düzenine ilişkin memnuniyetsizlik nedenlerinin "bireysel eşya isteği", "dersliğe ait olumsuz özellikler" ve "olumsuz davranışsal özellikler" temaları altında toplandığ görülmüştür.

Yatakhaneye ilişkin koku memnuniyetsizliğinin nedenlerinin "birey kaynaklı koku" ve "yanlış yatakhane düzeni kaynaklı koku" temalarını kapsayan "yatakhaneye içi kaynaklı" ana teması altında toplanmıştır. "Hizmet eksikliği/yetersizliği", "bina yapım yanlışlıği/eksikliği" ve "bireylerden kaynaklanan koku" temaları "yatakhane dişı kaynaklı" ana teması altında toplanmıştır. Yatakhanenin boyutuna ilişkin memnuniyetsizlik nedenlerinin "yapı yanlışlığı" teması altında toplandığı belirlenmiştir. Yatakhanenin eşya rengi ve düzenine ilişkin memnuniyetsizlik nedenleri "bireysel eşya isteğii", "olumsuz davranış özellikleri", "eşyaların olumsuz özellikleri”, "hizmet yetersizliği”, "yatakhanenin olumsuz özellikleri” ve "yatakhane ile ilgili olumsuz duygular" temaları altında toplanmıştır. Yatakhaneye ait gürültüye/sese ilişkin memnuniyetsizlik nedenlerinin "yatakhane içi kaynaklı" ve "yatakhane dışı kaynaklı" ana temaları altında toplandığı belirlenmiştir. "Yatakhane içi kaynaklı gürültü" ana teması altında "yanlış yatakhane düzeni" ve "olumsuz birey davranışları" temaları 
bulunduğu görülmüştür. Yatakhanenin duvar rengine ilişkin memnuniyetsizlik nedenlerinin "kişisel beğenilerle ilgili nedenler" ve "renk dışı etkenler/sorunlar" temaları altında toplandığı belirlenmiştir.

Bahçenin oturma yerlerine ilişkin memnuniyetsizlik nedenlerinin "oturma yerlerinin eksikliğì", "uygun olmayan yerlere oturma şikâyeti” ve "zemin şikâyetleri”" temaları altında toplandığı bulgulanmıştır. Bahçenin oyun/spor araçlarına ilişkin memnuniyetsizliğinin nedenleri "okul içi etkenler/yetersizlikler" ve "okul dışı etkenler" temaları altında toplanmıştır. Bahçenin temizliğine ilişkin memnuniyetsizlik nedenleri "olumsuz birey davranışları", "çevresel nedenler", "yapısal nedenler/eksiklikler” ve "hizmet eksikliği" temaları altında toplanmıştır. Bahçe güvenliğine ilişkin memnuniyetsizlik nedenlerinin " hizmet eksikliği” ve "okul dişı etkenler" temaları altında toplandığı belirlenmiştir. Bahçenin görünümüne ilişkin memnuniyetsizlik nedenlerinin "sağlıssız alanların olması", "bahçe zeminine ilişkin şikâyetler" ve "yeşil/ağaç görünümü eksikliği" temalarının altında toplandığ bulunmuştur.

Yorumlayıcı analiz sonucu elde edilen bulguların, her okulda ve eğitim biriminde aynı çıkması ortak kavramsal çerçeveye ulaşılmasını sağlamıştır. Başka deyişle, YİBO'larda tüm derslik, yatakhane ve bahçede tespit edilen fiziksel/mekânsal sorunların nedenlerinin aynı kavramsal temele dayandığı ortaya çıkmıştır. Böylece sorunların genel nedenlerine ilişkin kavramsal bir model elde edilmiştir.

Tablo 16: Tüm okulların ilgili mekânsal birimlerinde memnuniyetsizlik nedenlerine ilişkin nitel verilerin birlikte değerlendirilip, yorumlanması sonucu ulaşılan kavramsal çerçeve

\begin{tabular}{|c|c|c|}
\hline YİBO Derslik & YİBO Yatakhane & YİBO Bahçe \\
\hline $\begin{array}{l}\text { Mekân-Birey döngüsel } \\
\text { etkileşimi }\end{array}$ & Mimari/yapısal özellikler & Mimari/yapısal özellikler \\
\hline $\begin{array}{l}\text { Mekân-Mekân etkileşimli } \\
\text { bütünlüğü }\end{array}$ & $\begin{array}{l}\text { Mekân-Birey döngüsel } \\
\text { etkileşimi }\end{array}$ & $\begin{array}{l}\text { Mekân-Birey döngüsel } \\
\text { etkileşimi }\end{array}$ \\
\hline $\begin{array}{l}\text { Mekânı benimseme } \\
\text { (Bireysel/özel alan) } \\
\text { gereksinimi }\end{array}$ & $\begin{array}{l}\text { Mekânı benimseme } \\
\text { (Bireysel/özel alan) } \\
\text { gereksinimi }\end{array}$ & $\begin{array}{l}\text { Mekânı benimseme } \\
\text { (Sosyal/özel alan) } \\
\text { gereksinimi }\end{array}$ \\
\hline Mimari/yapısal özellikler & $\begin{array}{l}\text { Mekân-Mekân etkileşimli } \\
\text { bütünlüğü }\end{array}$ & $\begin{array}{l}\text { Mekân-Mekân etkileşimli } \\
\text { bütünlüğü }\end{array}$ \\
\hline
\end{tabular}

Tablo 16'da görüldüğü gibi araştırmanın problemine uygun olarak her mekânsal birime ait memnuniyetsizlik nedenleri dört tema altında kavramsallaştırılmıştır. Bunlar "mekân-birey etkileşiminin döngüsü", 
"mekânların kendi içlerinde ve diğerleriyle bütünsellik göstermesi", "özel/sosyal mekân oluşturma gereksinimi" ve "yapısal/mimari yetersizliklerin insan davranışına etkileri" olarak bulgulanmıştır.

\section{TARTIŞMA VE SONUÇ}

Mekân ve birey/öğrenci bir bütünün parçalarıdır ve birbirlerini etkilemektedir. Heideger, hermeneutik-fenomonolojik bir bakış açısıyla, bir mekân içerisinde varolduğumuz zaman değil, mekânsal olarak varolduğumuz gerçeği üzerinde durarak, mekânın sadece algılanan ya da kavranan bir şey olmadığını, aksine var olma biçimimiz olduğunu düşünür (Akt. Hisargil, 2008). Bu çalışmanın bulgularında yer aldığ 1 gibi, mekânın dinamik bir parçası olan bireyin/öğrencinin, mekânsal sorunların da bir parçası olduğu söylenebilir. Öğrencilerin olumsuz davranışları ile mekânın olumsuz özelliklerinin, aynı sorunun nedenleri arasında olması, birbirleriyle etkileşimli olduğunu ve bu karşıllklı etkileşimden bir döngü doğduğunu ortaya çıkarmıştır. Bu konuda Gürkaynak (1988), çevre-birey ilişkisinin karşılıklı bir etkileşim olduğunu belirterek, bu etkileşimde çevrenin özellikle fiziksel çevrenin - insan davranışları ve deneyimleri üzerinde çeşitli ve önemli etkileri olduğunu, buna karşl1ık kişinin de çevresini anlamak, ona yönelik tutumlar geliştirmek, çevresel değişkenlerin üstesinden gelme gibi yollarla çevre üzerinde etkili olduğunu vurgulamıştır. Alkan (1979) çeşitli bina, donatım, model, düzenlemeler, sıcaklık, renk ve çeşitli objelerden oluşan çevrenin önce insanlar tarafından şekillendirildiğini, aynı çevrenin daha sonra da insanları şekillendirdiğini belirtmiştir.

Aslında, her birey kendi kişiliğinin, duygu ve düşüncelerinin kısacası kendisinin bir yansıması olan mekânda yaşamak ister. Bu ancak kendisiyle bütünlük kurduğu, kendisini yansitan, yani bireyselleştirebildiği ve benimseyebildiği alanlarda mümkündür. $\mathrm{Bu}$ araştırmada, öğrencilerin sadece kişisel/özel mekânlara özgü bir gereksinimi olmadığ1; akranlarıyla/arkadaşlarıyla paylaşabilecekleri sosyal/özel mekânlara da gereksinimleri olduğu ortaya çıkmıştır.

Bir mekân aynı bütünün parçaları olan diğer mekânlarla da etkileşim içindedir. Örneğin, YİBO'nun bütünselliği içerisinde yer alan derslik, yatakhane, bahçe arasında böyle bir durum vardır. Bu bütün içinde, bir mekândaki yetersizliğin ve eksikliğin, diğer mekânlarda olumsuzluğa yol açtığına ve bu yüzden bir okuldaki bir sorunu çözmeye çalışırken, birim mekânın diğer mekânlarla oluşturduğu bütünselliğe dikkat etmek gerekmektedir. Gürkaynak (1988) fiziksel çevrenin, birçok alt sistemden oluşmuş bir sistem olarak ele alındığında; bu sistemin her düzeyinde, davranışı etkileyecek fiziksel özellikler var olduğunu ve her düzey kendi 
içinde bir bütün olmakla birlikte, diğer düzeylerle birlikte, sistemin bir parçası olduğunu belirtmiştir. Hollahan'ın, bütüncül olarak adlandırdığı modelde, fiziksel çevre birbirini kuşatan, iç içe geçmiş bağlamlar olarak düşünülür (Akt. Gürkaynak, 1988). Platonun Chora anlayış1; mekan varsa, bir başka mekan içerisinde yer almalıdır ve bu mekanda bir başkasında.... (Hisargil, 2008) şeklinde tanımlanmıştır.

YİBO'ların mimari yapısı öğrencilerin bilişsel, duyuşsal, psikomotor gereksinimlerini ve yaşamsal ve psikolojik ihtiyaçlarını karşılayacak şekilde inşa edilmelidir. Bu yüzden okullar, özellikle öğrencilerin tek yaşam alanı olan YİBO'lar, inşa edilirken, bu süreçte öğrenci gereksinimlerinden haberdar olan eğitimciler de görev almalıdır. Bu konuda John Dewey (1924) "Türkiye eğitimi hakkındaki birinci rapor" un ilk maddesine "Okul binaları ile donanımı ve okul mimarisi, yeni okulların en önemli temel konularından biri olduğu için bu alanda birkaç uzman yetiştirmek için bütçeye tahsisat konmalıdır. $\mathrm{Bu}$ uzmanlar bilahare vekilliğin mebani (binalar, yapılar) müdüriyetini teşkil edeceklerdir" yazmıştır. İkinci rapor olan iptidai (başlangıç) raporda ise "Okul inşaatı - Eğitim bakanlığında, okul binaları, okul donanımı ve sağlığı ile ilgilenen ayrı bir şube bulunmalıdır. Herhangi tecrübeli bir mimarın öğretmenlerden az çok fikir alarak bir okul binası yapabileceğini, bina sorununun sadece mimarla, güvenle okul yöneticilerine bırakılmasını yeterli olacağını zannetmek büyük bir hatadır" şeklinde belirtmiştir. Yine aynı raporda "Bu (eski) eğilim devam ettiği sürece eskiden olduğu tarzda okul binaları inşasına devam edilecek ve para gerçek eğitim ihtiyaçlarını tatmin etmekten ziyade okulun dış görünüşüne harcanmış olacaktır. Bu şube ilk ve ikinci derecede okullar işlerine, eğitim amaçları ve araçları ile okulun binası ve bahçesi arasındaki münasebetlere ve hava, 1 şı sıra tuvalet teşkilatı vb. gibi meseleleri bilen uzmanlardan meydana gelmelidir" şeklinde uyarıda bulunmuştur.

$\mathrm{Bu}$ araştırma göstermiştir ki Türk eğitim tarihinde önemli etkileri olan John Dewey'in Cumhuriyetin ilk yıllarında vurguladığı sorunlar günümüzde devam etmektedir. Okulların dışarıdan içeriye tüm mekânları bir bütünsellik içinde öğrenci görüşü alınmadan, eğitim programlarına uygunluğu tartışılmadan, inşa edildiği/kurulduğu sürece düzenlenen eğitim ortamları, eğitim için yetersiz ya da hatalı olacaktır. $\mathrm{Bu}$ durum, mekân/okul ile birey/öğrenci etkileşiminin döngüsünü olumsuz etkileyecektir Bu durumda gereksinimleri karşılanmayan öğrenci mekânı benimseyemeyecektir ve değiştirmeye çalışacaktır. Değiştiremezse ya öğrenilmiş çaresizlikle yaşayacak ya da tahrip edecektir. 


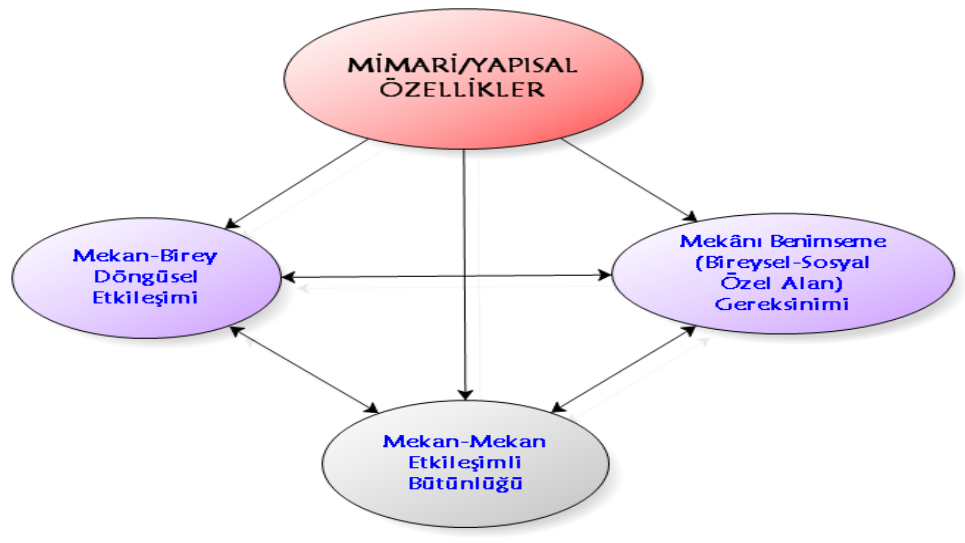

Model 2. Tüm okulların ilgili mekânsal birimlerinde, memnuniyetsizlik nedenlerinden elde edilen nitel verilerin, birlikte değerlendirilip, yorumlanması sonucu ulaşılan kavramsal model

Mimari/yapısal özelikler, hem mekân-birey, mekân-mekân etkileşimini hem de bireyin mekânı benimsemesini etkileyen, öncelikli olgudur. Mekân birey ilişkisi, mekânı benimseme ve mekânların kendi aralarındaki etkileşimi birbirini karşı1ıklı olarak etkilerken, mimari yapısal özellikler bu olguların üçünü birden baskın olarak etkilemektedir. Bu sonuç da bu araştırmanın son sözünün okul mimarisinin/okulların kendine özgü inşası olması gerektiğini göstermektedir.

Sonuç olarak, Türkiye'nin Mimarlık, Eğitimbilim ve Çevresel Psikoloji (mekânsal psikoloji) alanlarının ortak paydası olan eğitim mimarisine duyduğu ihtiyaç ortaya çıkmıştır. Eğitim mimarisi alanının kuramsal yapısı disiplinlerarası çalışmalarla bir an önce tamamlanmalı ve uygulamada yerini alması sağlanmalıdır.

\section{ÖNERILER}

1) Türkiye'deki tüm eğitim kurumları için Eğitim/Okul mimarisi alanı oluşturulması bu çalışmanın temel önerisidir; bu alanın kuramsal ve kurumsal yapısı oluşturulmalı, eğitimbilimlerinin etkin bir alanı olmalıdır.

2) Türk eğitim sisteminde önemli bir yeri/gerekliliği olan YİBO'lar üzerine daha fazla eğitbilim araştırması yapılması önerilebilir.

3) Eğitim yapılarının, planlanma aşamasından, inşa aşamasına kadar olan her sürecinde eğitimbilimcilerin ve eğitim ortamlarının kullanıcılarının görüşleri alınmalıdır. 
4) Eğitim ortamları kurulurken, mekânın ve bireyin/öğrencinin bir bütününün parçaları olduğu, birey mekân etkileşiminin döngüselliği ve mekân-mekân etkileşiminin döngüselliği dikkate alınmalıdır.

5) Eğitim ortamlarının, öğrencilerin bireyselleşmesine yardımcı olacak şekilde özel alan istekleri, mekânı benimseme gereksinimleri, kısaca psikolojik ve estetik ihtiyaçları göz önüne alarak düzenlenmesi gerekmektedir.

6) D1ş mekân olan bahçe, öğrencilerin bilişsel, duyuşsal ve psikomotor gelişimlerini, oyun gereksinimleri dikkate alınarak, daha işlevsel düzenlemelere kavuşturulmalıdır.

7) $\mathrm{Bu}$ araştırmada bütünsellik bağlamında ele alınan fiziksel/mekânsal değişkenlerin her biri tek tek incelenerek tamamlayıcı araştırmalar yapılabilir.

8) Eğitim programlarının geliştirilmesi çalışmalarında eğitim mekânlarının özellikleri dikkate alınmalıdır.

\section{KAYNAKLAR}

Akar, R ve Sadık, F. (2003). İlköğretim Binalarının Fiziksel Açıdan Değerlendirilmesi. Eğitim ve Bilim Dergisi, 28 (130), 16-23.

Akgül, A. ve Çevik, O. (2003). İstatiksel Analiz Teknikleri. Ankara: Emek Ofset

Alkan, C. (1979). Eğitim Ortamları. Ankara Üniversitesi Eğitim. Ankara Fakültesi Yayınları. No: 85.

Baş, T. ve Akturan, U. (2008). Nitel Araştırma Yöntemleri, Nvivo7 ile Nitel Veri Analizi. Ankara: Seçkin Yayıncılık.

Başar, M. A. (2000). "İlköğretim Okullarının İşgören ve Fiziki Olanakları (4. Ulusal Sınıf Öğretmenliği Sempozyumunda Sunulmuş Bildiri). Pamukkale Üniversitesi Eğitim Fakültesi Dergisi, (8), Denizli: Pamukkale Üniversitesi.

Başaran, İ.E.(1994). Eğitime Giriş. Ankara: Kadığlu Matbaası (4. Baskı)

Başbakanlık Aile Araştırma Kurumu, (1999). Türk Ailesinin Yaşadı̆̆ Mekânlara/Konulara İlişkin Eğilimler. Birinci Cilt. Bilim Serisi:114

Başkan, T.B. ve Sözen M.Ş.(2006).Dersliklerde Görsel Konfor ve Etkin Enerji Kullanımı-Bir Örnek Derslik Aydınlatması.Yıldız Teknik Üniversitesi Mimarlık Fakültesi e-Dergisi,1(2-3), 143-153.

Baykal, A. (2004). Program Geliştirme Yaklaşımlarında Alansal Bağlam. XIII. Ulusal Eğitim Bilimleri Kurultayl. Malatya: İnönü Üniversitesi Eğitim Fakültesi.

Büyüköztürk, Ş. (2008). Sosyal Bilimler İçin Veri Analizi El Kitabı. Ankara: PEGEM Akademi. 
Çınar, C., Çizmeci, F. ve Akdemir, Z. (2007). 8 Yıllık Temel Eğitim Okullarında Müfredatın Gerektirdiği Mekân Standartlarının İstanbul Okulları Üzerinden Analizi. Yıldız Teknik Üniversitesi Mimarlık Fakültesi e-Dergisi, 2(4)188-203.

Çınkır, Ş. (1996). Okul Büyüklüğ̈̈nün Öğrenci Başarısı İle İlişkisi. Yüksek lisans Tezi, Ankara: Ankara Üniversitesi, Eğitim Bilimleri Fakültesi.

Dewey, J. (1939). Türkiye Maarifi Hakkında Rapor. İstanbul: Devlet Basımevi.

Dinç, P. ve Onat E. (2002). Bir İlköğretim Yapısının Bina Programı ve Tasarımı Bağlamında Değerlendirilmesi. Gazi Üniversitesi Mühendislik Mimarlık Fakültesi Dergisi, 17( 3)35-55.

Dönmez, B. (2008). "Okul ve Sinıf Ergonomisi ya da İnsanı Öncelemek." Eğitime Bakış Dergisi, Nisan, Mayıs, Haziran (11).

Edgü, E. ve Ünlü, A. (2003). Konutlarda Mekansal Dizin Verilerinin Mekan Tercihleri İle İlişkisi, Faktörler. İtüdergisi/a mimarlı, plamlama, tasarım, 2(1)27-40

Ekiz. D. (2003). Eğitimde Araştırma Yöntem ve Metotlarına Giriş. Ankara: Anı Yayınc1l1k.

Ergün, M. (1995). Bilimsel Araşttrmalarda Bilgisayarla İstatistik Uygulamaları. Ankara: Ocak Yayınları.

Ersoy, A. (2005). İlköğretim Bilgisayar Dersindeki Sınıf Yerleşim Düzeni ve Öğretmen Rolünün Yapılandırmacı Öğrenmeye Göre Değerlendirilmesi. The Turkish Online Journal of Educational Technology-TOJET [Elektronik Dergi], 4(4)170-181

Fidan N. ve Erden, M. (1998).Eğitime Giriş. İstanbul: Alkım Yayınları.

Freedman, J.L., Sears, D.O. ve Carlsmith, J.M. (1989). Sosyal Psikoloji. (Çev. Ali Dönmez). İstanbul: Ara Yayıncılık.

Gömleksiz M., Kilimci, S., Vural, R.A., Demir Ö., Meek Ç.K., Erdal, E. (2008).Okul bahçeleri Mercek altında: Şiddet ve Çocuk hakları üzerine Nitel Bir Çalışma. İlköğretim Online Dergisi, 7(2)273-287.

Güçyılmaz, N. (1983). Az ya da Çok Çocuklu Ailelerden Gelen Klz ve Erkek Çocukların Günlük Yaşamları. Yayınlanmamış Yüksek lisans Tezi, Ankara: Ankara Üniversitesi, Eğitimbilimleri Fakültesi, Ankara.

Günal B. ve Esin N. (2007). İnsan - Mekân İletişim Modeli Bağlamında Konutta Psiko-Sosyal Kalitenin İrdelenmesi. İtüdergisi/a mimarlık, plamlama, tasarım, 6 (1), 19-30.

Gürkaynak, İ. (1988). Çevresel Psikoloji: Doğası, Tarihçesi, Yöntemleri. Ankara Üniversitesi Eğitim Bilimleri Fakültesi Dergisi, 21(1)1-9.

Güven, B. \& Karataş, İ. (2004). İlköğretim Matematik Öğretmen Adaylarının Sınıf Ortamı Tasarımları. Ilköğretim-Online Dergisi, 3(1),25-34. (http://ilköğretim-online.org.tr, Ulaşım Tarihi; 22.06. 2009) 
Hisargil, B.O. (2008). Martin Heidegger'de "Mekân” Düşüncesi: Hermeneutik-Fenomonolojik Bir Yaklaşım. Erciyes Üniversitesi Sosyal Bilimler Enstitüsü Dergisi. (25)23-34.

Holahan, C.J. (1982). Environment Psychology. Newyork: Random House.

İmamaoğlu, O. (1997). İnsan Çevre Toplum. (Ed. R. Keleş). Ankara: İmge Kitabevi.

Karaküçük, S. (1999). Ev Dişında Çalışmayan Farklı Sosyo-Ekonomik Yapıdaki Kadınların Etkinlik Sinırı. Altıncı Ulusal Sosyal Bilimler Kongresi. Ankara: Orta Doğu Teknik Üniversitesi.

Karaküçük, S.A. (2004). Bir Mekânsal Paradigma Olarak Öteki: Kurgusal Metinlerde Ötekilerin Mekânlarına İlişkin Bir İnceleme. Eğitim Toplum Bilim Dergisi. 2 (8), 76-90.

Kelekçi, L.Ö ve Berköz L. (2006). Konut ve Çevresel Kalite Memnuniyetini Yükselten Faktörler. İtü Dergisi/a mimarlık, plamlama, tasarım, 5(2) $165-176$.

Kuş, E. (2006). Sosyal Bilimlerde Bilgisayar Destekli Nitel Veri Analizi. Ankara: Anı Yayıncılık.

Manav, B. ve Küçükdoğu, M.Ş. (2006). Aydınlık Düzeyi ve Renk Sıcaklığının Performansa Etkisi. Ittüdergisi/a mimarlı, planlama, tasarim, 5(2)3-10.

MEB. (2008). Yatılı İlköğretim Bölge Okulları Yönetici Kılavuzu. Ankara: MEB.

Özer, N. ve Dönmez, B. (2007). Okul Güvenliğine İlişkin Kurumsal Etkenler ve Alınabilecek Önlemler. Milli Ë̆itim Dergisi, (173)299-313.

Punch, K.F. (2005). Sosyal Araştırmalara Giriş. Ankara: Siyasal Kitabevi.

Saillard, E.K. (2009). Nvivo8 ile Nitel Araştırma Projeleri. Ankara: Anı Yayınc1lık.

Şencan, H. (2005). Sosyal ve Davranışsal Ölçümlerde Güvenilirlik ve Geçerlilik. Ankara: Seçkin Yayıncılık.

Ünal, S., Öztürk, M. ve Gürdal A. (2000). "İlköğretim Okullarının Bina Standartlarına Uygunluğu". Pamukkale Üniversitesi Ĕgitim Fakültesi Dergisi, (http://egitimdergi.pamukkale.edu.tr/makale/say\%.pdf.Ulaşım Tarihi: 28.09.2009)

Yaman, E. (2006). Eğitim Sistemindeki Sorunlardan Bir Boyut: Büyük Sınıflar ve Sınıf Yönetimi, Gazi Üniversitesi Türk Eğitim Bilimleri Dergisi, 4(3)261-274.

Yıldırım, A. ve Şimşek, H. (2005). Sosyal Bilimlerde Nitel Araştırma Yöntemleri. Ankara: Seçkin Yayıncılık.

Yıldırım,K., Hidayetoğlu, M.L. ve Şen, A. (2007). Farklı Mimari Biçimlerdeki Kafe/Pastane Mekânlarının Kullanıcılarının Alg1- 
Davranışsal Performansı Üzerine Etkisi. Politeknik Dergisi, 10(3)295301.

Yılmaz, S. ve Bulut, Z., (2002). Kentsel Mekânlarda Çocuk Oyun Alanları Planlama İlkeleri. Ziraat Fakültesi Dergisi, 3, Erzurum.

Yurtal, F. (2007). "İlköğretim Okullarındaki Rehberlik Servislerinin Mekân, Donanım, Ekipman ve İnsan Kaynakları Açısından Durumu", Milli Eğitim Dergisi, (173).

Yüksel, N. (2005). Günümüz Kamu Kurumlarında Yapısal Konfor Koşullarının Tespit Edilmesine Yönelik Bir Çalışma. Uludă̆ Üniversitesi Mühendislik-Mimarlık Fakültesi Dergisi, 10(2)21-31. 
